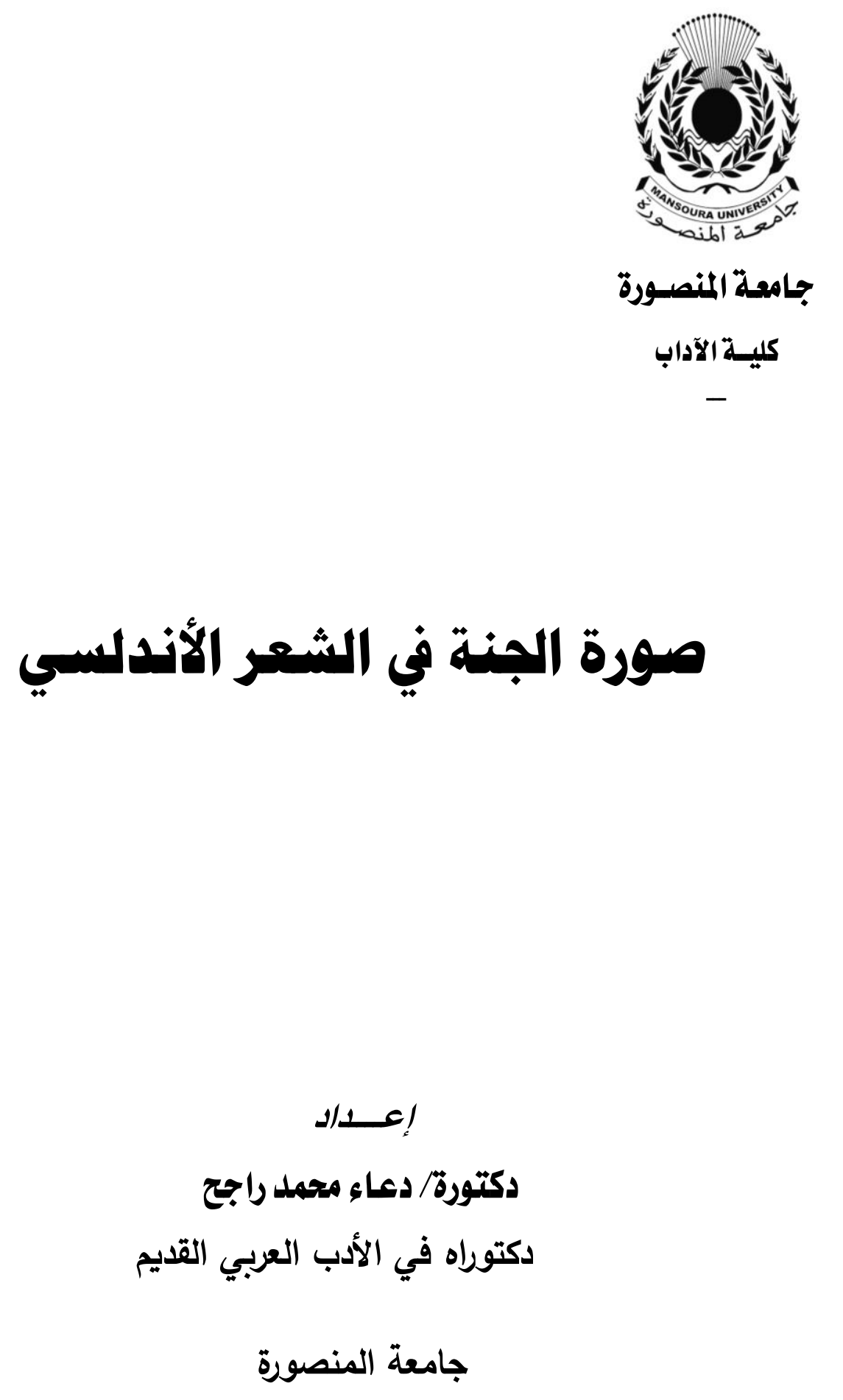




\section{صورة الجنة في الشعر الأندلسي}

\section{د/ دعاء محمد راجح}

1- تمهيد : تحدثت فيه عن أسماء الجنة كما

المقلمــة :

وردت في القرآن الكريم ومايحمله كل اسم

الحمد الله رب العالمين نحمده ونستعينه، والصـلاة

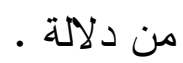

r- أســــاء الجنة في الثــــر الأندلسي.

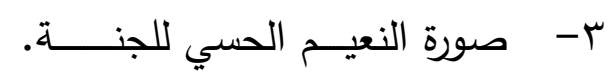

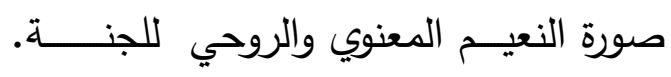
والسلام على هادي الأمة وخاتم الأنبياء والمرسلين

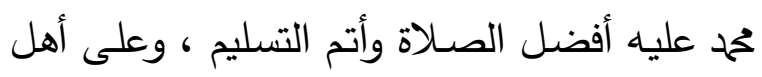
بيتهـ الطيبين الطـاهرين ، والتابعين لهم بإحسـان إلى يوم الدين - لماين المين

التمهيد إن كلمة الجنة من الكلمات التي وردت كثيراً في التي

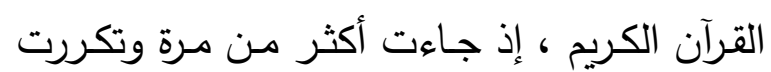

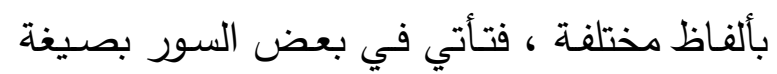

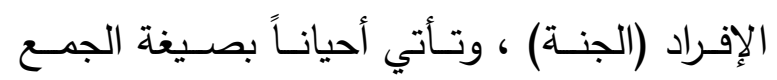

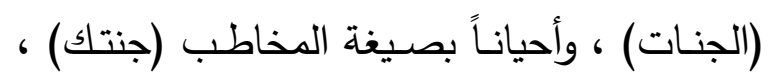
وصيغة الغائب (جنته) ، لكن جميع هذه الألفاظ والنا

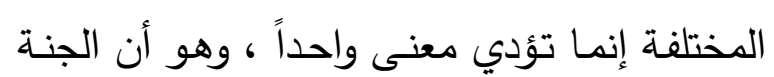

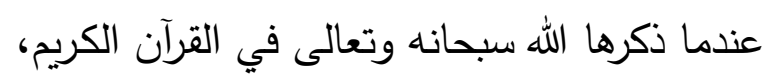

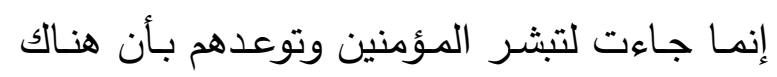

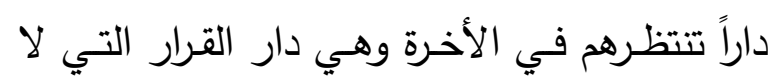
نهاية لها . وقـد ذكـر القـرآن الكـريم أوصـاف الجنـة تشـويقاً للمؤمنين ، ووعدهم بأن كل إنسان يعمل صالحاً

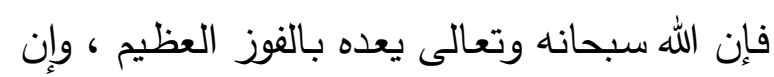
الله لا يخلف الميعاد مع عباده المؤمنين . وقد وردت الجنة في القرآن الكريم بصيغ متعددة ،

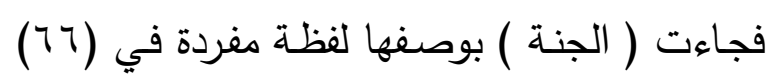

أما بعد .... فقد كان للجنة أثر عظيم في نفوس . لمان

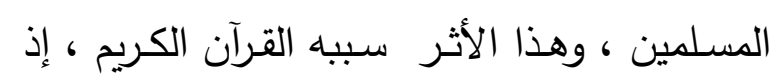

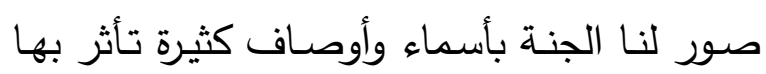
المسلمون وكذلك الثعراء إذ أنهم استلهموا وصفها باء في القـرآن الكـريم والحـديث الثـــيف ، وأطلقــوا

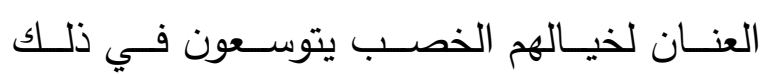
النطاق، ويطورون هذه الصورة ويزيدون عليها،

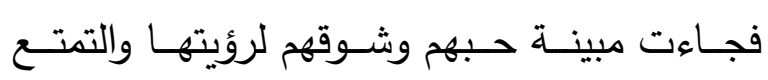
بملذاتها . فالبيئة الأندلسية ،قد حباها الله بجمال لم تتصف بكف به أية بيئة أخرى في ذلك الوقت ، فكانت الأندلس لالس النس

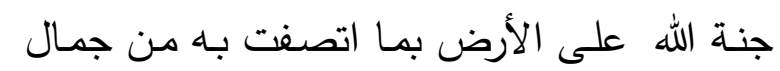

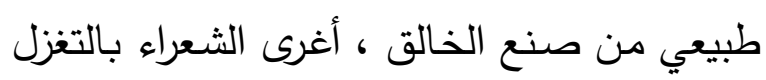

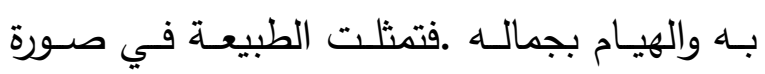

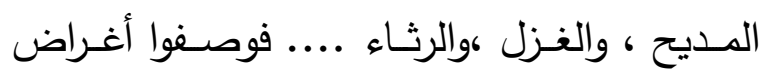

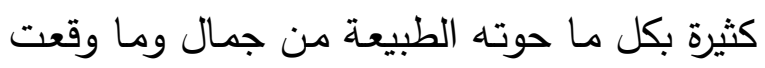
عليه أعين الثعراء من مواد. وقدمت بحثي موزعاً على: 


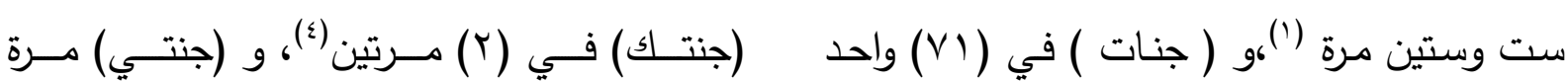

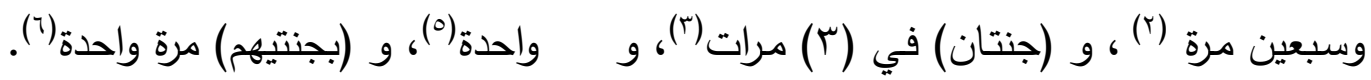

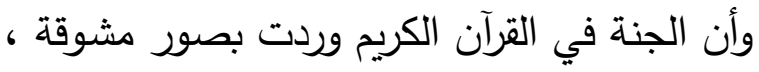
وأسماء مشرقة ، وقد منحها الخالق جل وعلا كل فئل هذه السمات لما تستحقه من وصف بديع وفئ وصور تدفع بالمتلقي إلى نوالها والفوز بنعيمها ـ الف ولنا بعد ذلك أن نقف بن عند أهم أسماء الجنة كما احتوتها النصوص القرآنية ، وما

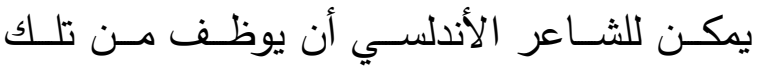

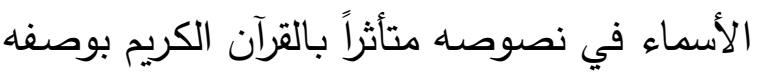

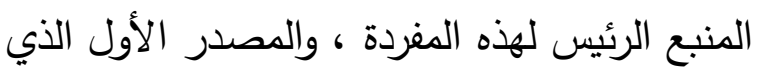
وقف عندها ، ومن تلك الأسماء:

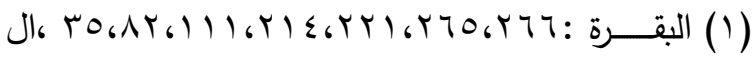

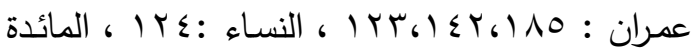

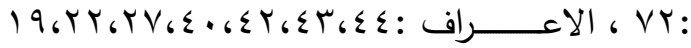
، •

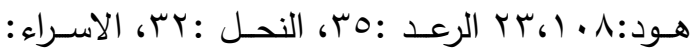

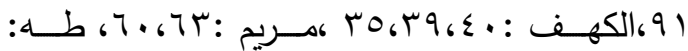

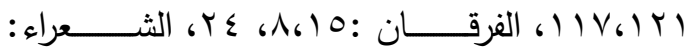

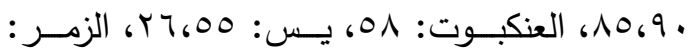

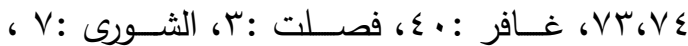

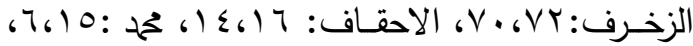

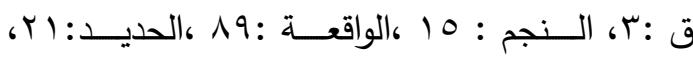

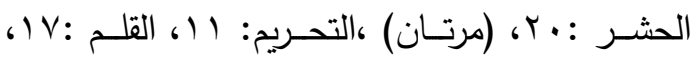

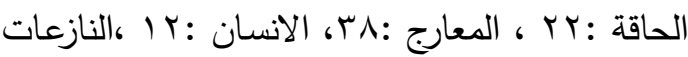

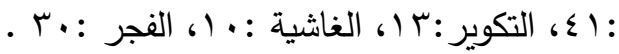

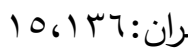

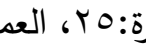

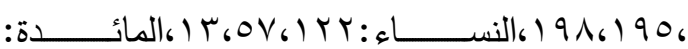

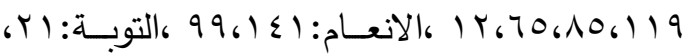

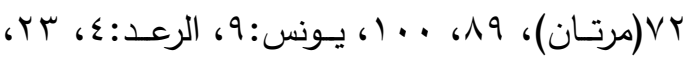

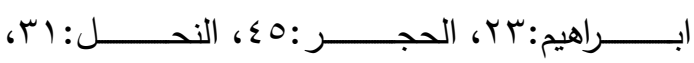

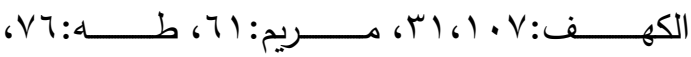

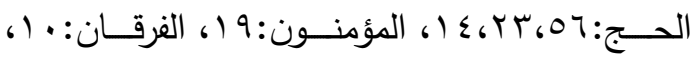

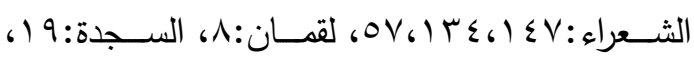

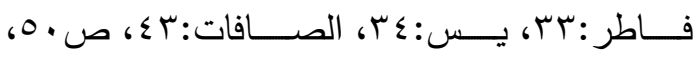

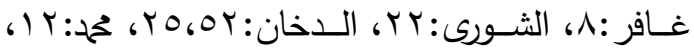

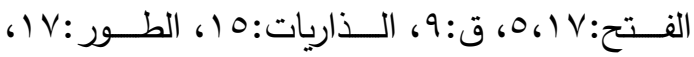

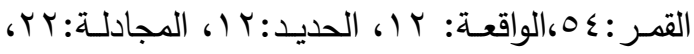

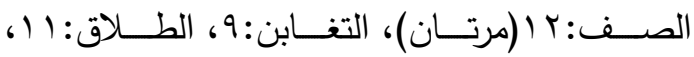

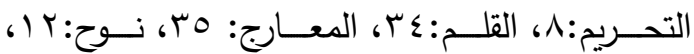

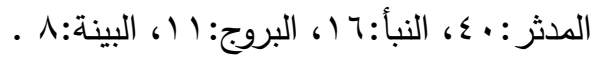




\begin{tabular}{|c|c|c|}
\hline دلالة الاسم & الشاهد القرآني & أسماء الجنة \\
\hline 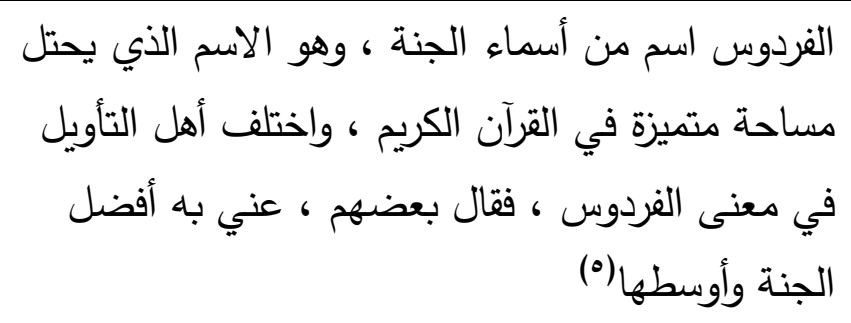 & 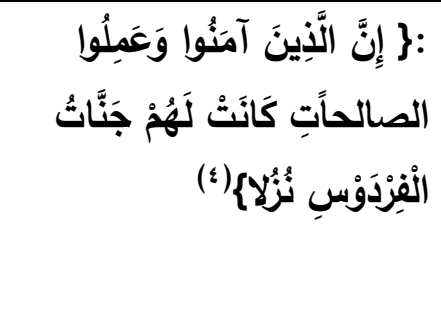 & الفردوس \\
\hline 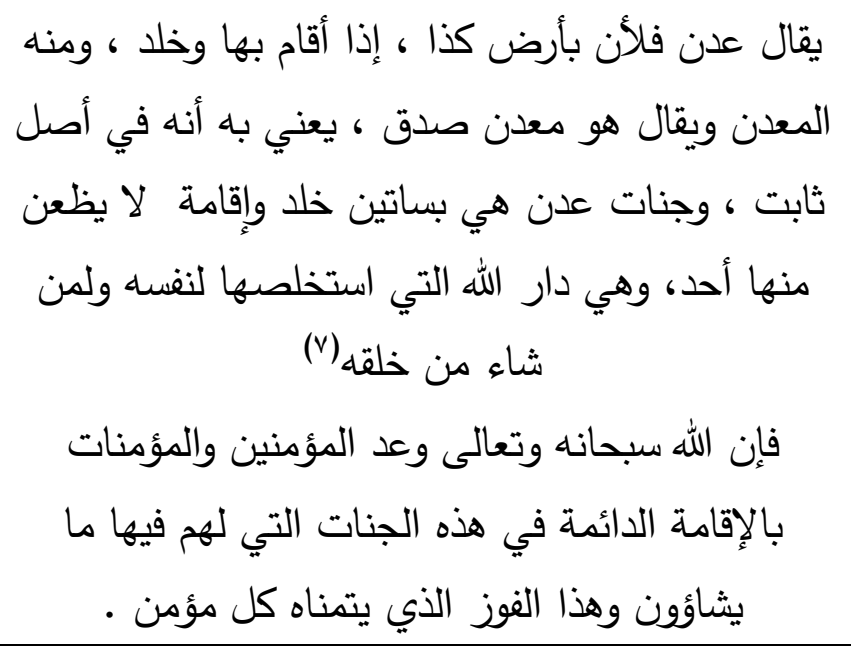 & 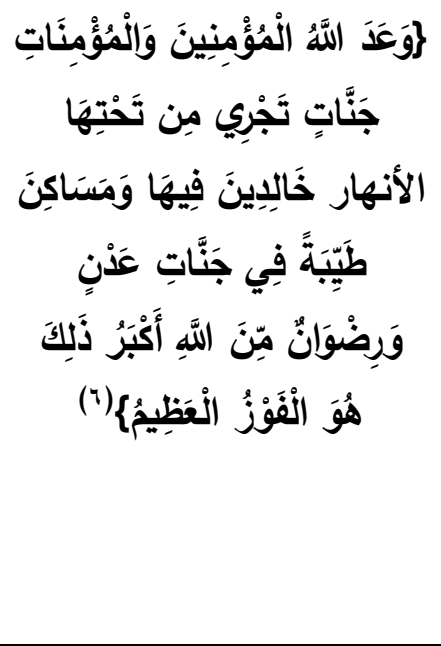 & جنـــات عدن \\
\hline 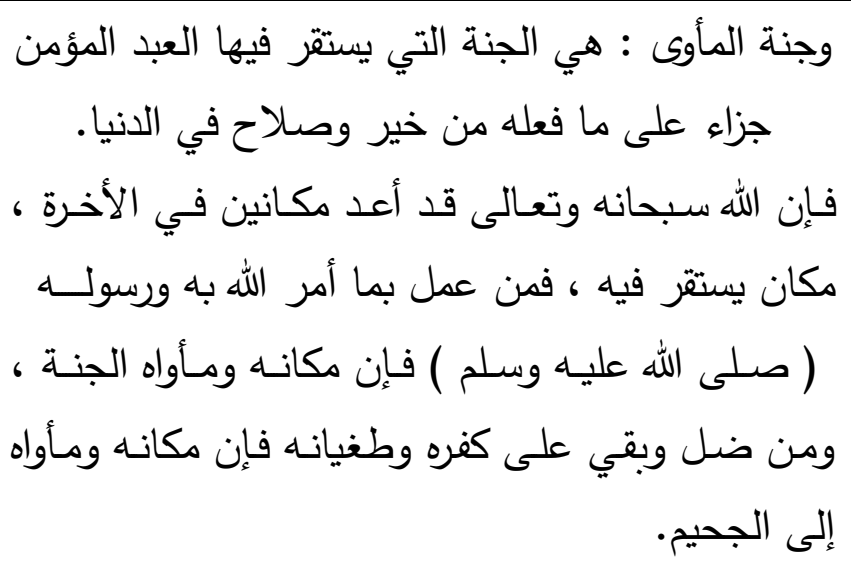 & 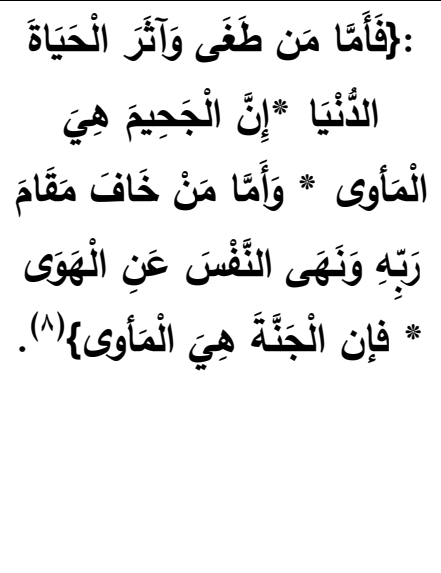 & 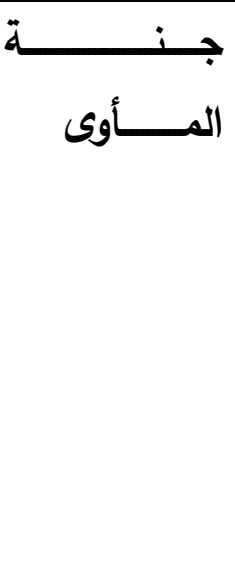 \\
\hline
\end{tabular}

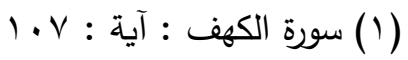
(ץ) جامع البيان عن تأويل آي القرآن، لأبي جعفر محمد بن جرير الطبري ، تحقيق الدكتور عبد الله بن عبد الحسن التركي ، ج

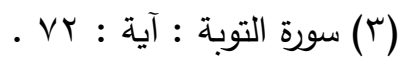

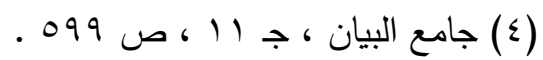

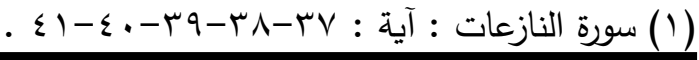




\begin{tabular}{|c|c|c|}
\hline 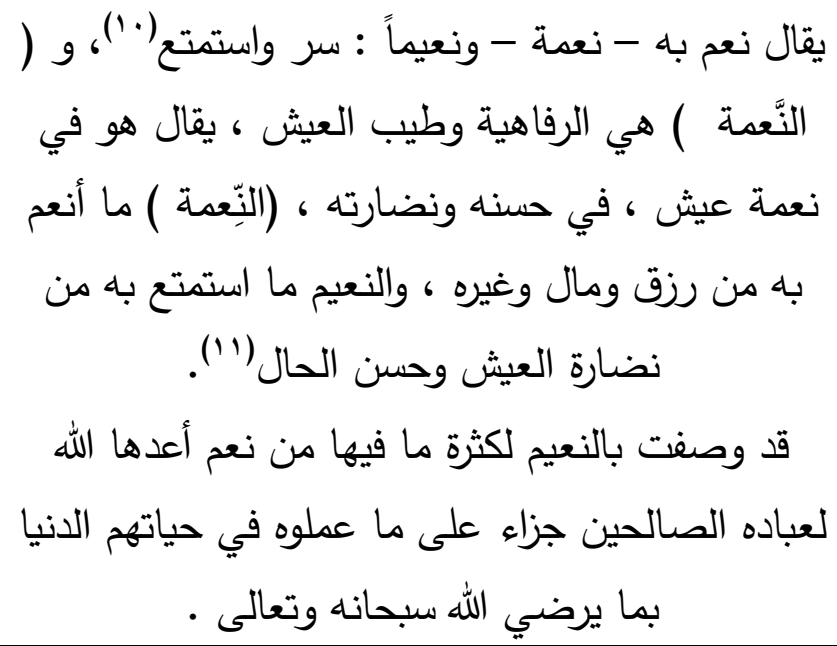 & 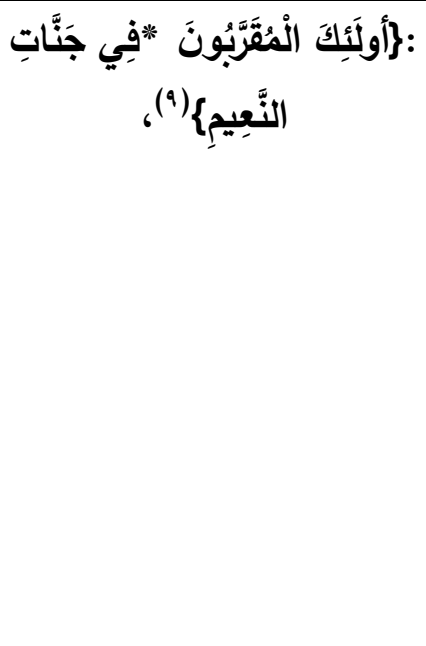 & ــات \\
\hline الخلد هو البقاء ، وقد جاءت الجنة مقترنة بصفة الخلد & 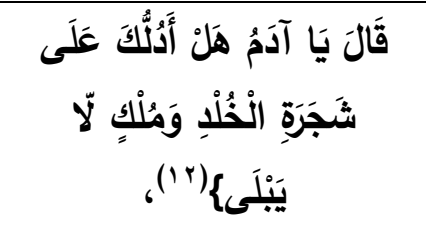 & الخل \\
\hline 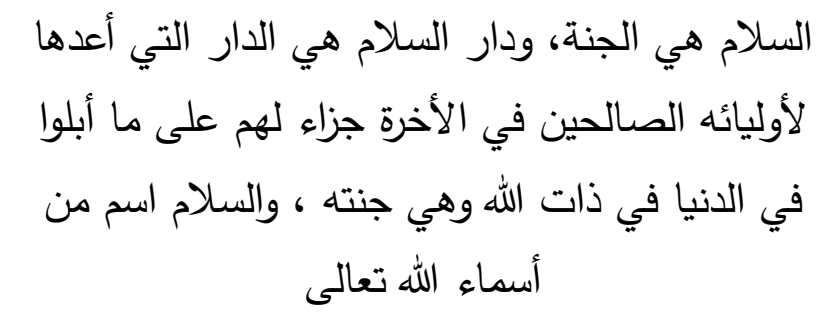 & 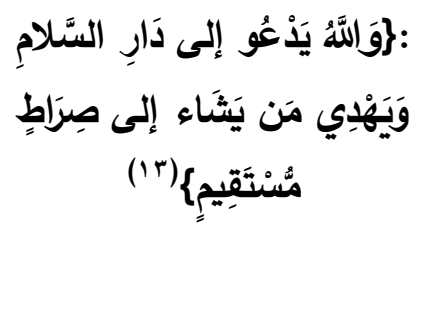 & سلام \\
\hline 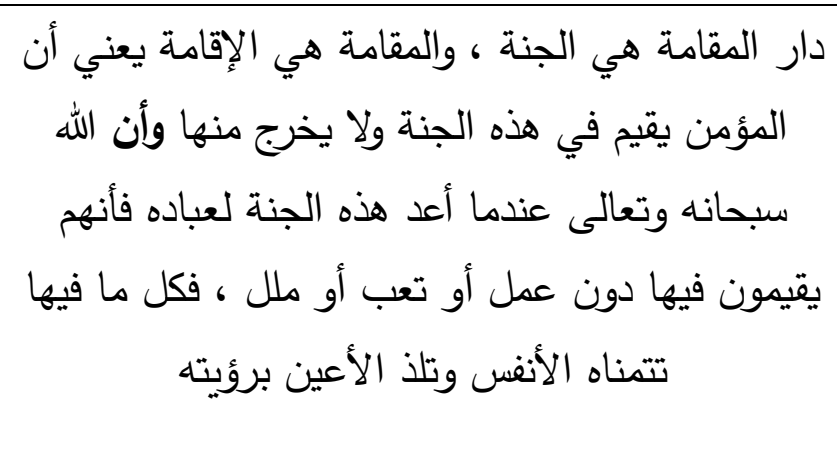 & 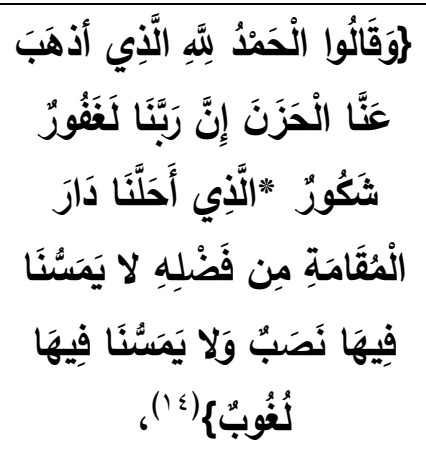 & 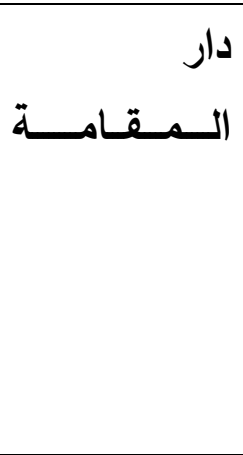 \\
\hline
\end{tabular}

(Y) سورة الواقعة : آية :

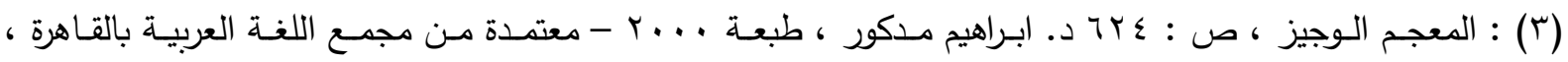

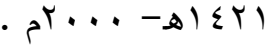

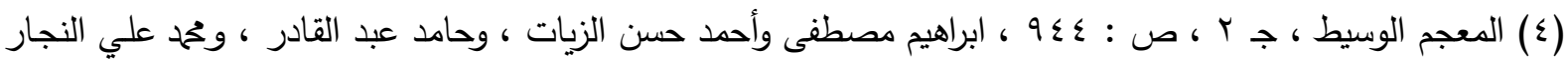

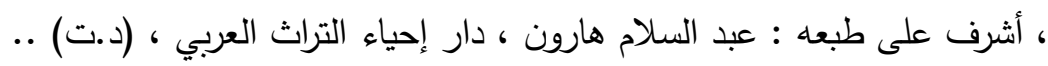

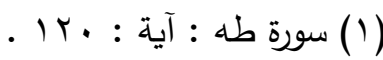

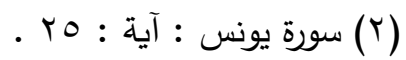

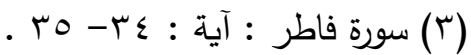


وحسـن العـيش والصــحة الدائمسـة ، قـال تعـالى

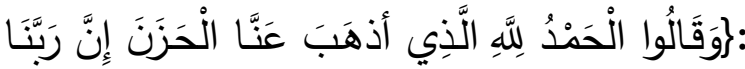
لَغَفْورُ شَكُورٌ \{(10) فالعبـد المـؤمن عندما يـرى النعيم الذي هو فيـه يشكر الله تعالى على نعيمـه وأنـه قد رحل عن تلك الدنيا الفانية التي لـم ير

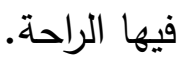

الأثر الايني في الشعر العربي: يكاد يقر المتتبع بوضـوح حقيقـة الأثر الـديني في عمـوم الثـعر العربي ولاسيما في العصسور المرافقـة لبزوغ نـور النبوة المحمدية ، ومن هنا فقد أخذ كل عصر من ،صسور الأدب العربي نصسيبه مـن هذا الأثر ولعل أكثر الشعراء تأثراً بالإسلام وقيمه ذلك الذي عاش في كنف عصر الدعوة والعقيدة ونعني بـا عصر الخلفاء الراشدين وأوائل العصر الأموي(") لمـا للإسـلام مـن أثر واضـح في نفوس أصـحابه وعقولهم ، إذ كان الشعراء شـوفين بقيم الرسـالة التي وجدت _هي الأخرى _ طريقها إلى نتاجهم الثعري. كما تأثر الثـاعر الأندلسي بالقرآن الكريم والسنة

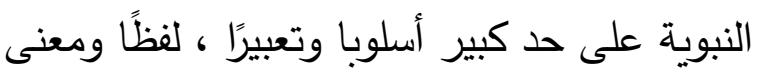
، وهذا التأثر لـه دوره الكبير في إحداث الروعـة والجمال في الثـعر ، بما يضفي نصيبا وافراً من الثـعور بأثر الكلمـات الإسـلامية في وجدان كل • مسلم

(1) سورة فاطر :آية: عَ . (1)

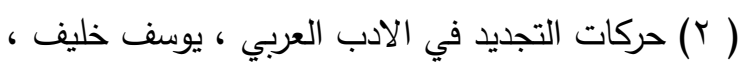
جـ ء ، ص qr الطبعة الأولى ، دار الكتب العلمية .
من خـلال مـا سبق فإن الجنـة قد جاءت بأسماء مختلفة وكثيرة ، فبعض هذه الأسماء قد اشتملت في تضـاعيف أسمائها وصف الجنـة وصفًا دقيقًا يبينين لنـا مـا فيها مـن متع وملذات تشـوق العبد المـؤمن إليهـا ، وبعـض هـــه الأسـماء قـد جــاء بصورة عامة دون أن يعرض لنا صفات الجنة إذ وده إذهاء جعلها صورة خفية لا يعلمها إلا صـانعها وخالقها الله سبحانه عالم كل شيء أما صفات الجنة وأهلها في القرآن الكريم ، فهناك نوعـان مـن الإدراك عنـــ الإنسـان هــا الإدراك الحسي والإدراك الذهني ، فالإدراك الحسي يكون عن طريـق الحواس ، فالإنسـان يعرف أي شـيء

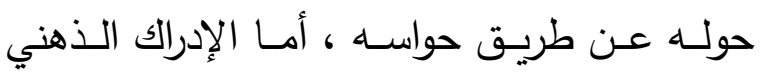
فتكون في إطلار العقل الإنساني وما ترسمه هذه

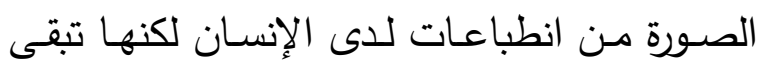

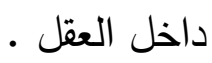
فالجنـة عنـدما وردت في النص القرآنسي جـاءت بصـور ومعـاًني مشـرفة تبقـى في أذهـان النـاس وتبقـى مخيــتهم تحتـوي هـــه الصــور الجميلــة

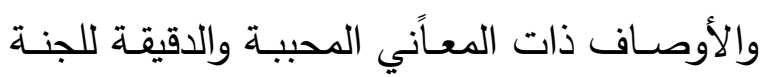
ليست موجودة في هذا الواقع الذي نعيشه ، فالجنة بعيدة كل البعد عن الواقع ممـا بقيت في أذهـان الناس كل" يتصورها حسبما يشاء وينطلق بخياله في الأفق الواسع • وقد بـين لنـا القرآن أوصـاف الجنـة ومـا فيهـا مـن أنهار وبساتين وقصور ،فيها تتتهي مرحلة العمل

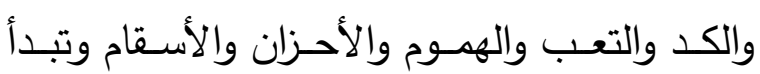
مرحلـة جديدة فيها الهناء والراحـة وصفاء البـال 
أحاديث النبي الكريم الشريفة من تفصيل لصفاتها الجنة في الشـــــر الأندلسي

ومتعهــا فأنــهـ يعطـي صــورة واضــحة متكاملــة وردت أســاء الجنـة في الثـعر الأندلسـي لتبـين الأطراف عن الجنـة ، وقد هيأ الجرد الإحصـائي الصـفات والتفاصـيل التـي رســـها شـعراء هـــا أن لفظة الجنة وردت في الثعر الأندلسي مجردة العصـر للجنـة متــأثرين بـذلك بالصـفات العامــة أو مضافة أو بأسمائها الأخرى (كالفردوس - جنة عدن - جنة الخلد - جنة المأوى - دار السلام ). والمفصـلة لهـا التـي رســها التـرآن الكـريم والتي أعدها سبحانه لعباده المتقين ، فضلاً عما ورد في

\begin{tabular}{|c|c|c|}
\hline الثاهد الشعري & اسم الشاعر & اسم الجنة \\
\hline و جنةٍ حلّ أهلُ النارِ ساحتهـا & قول ابن الإبّار & الجنـــــــة ، ومـن ورود لفظــة الجنــة \\
\hline 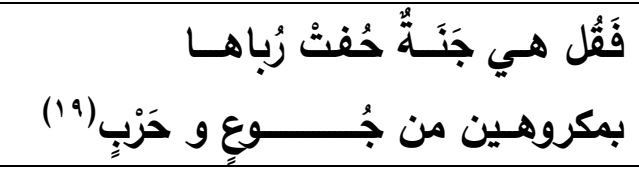 & قول أبو الحسن الحريق (^ا'): & الجنــــــة لفظة مجردة \\
\hline 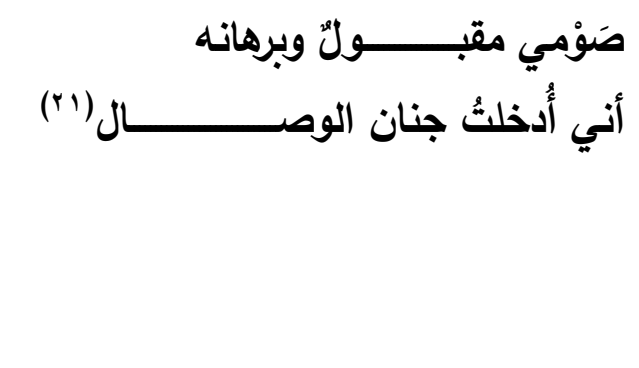 & قـــ أبـي بكـر & 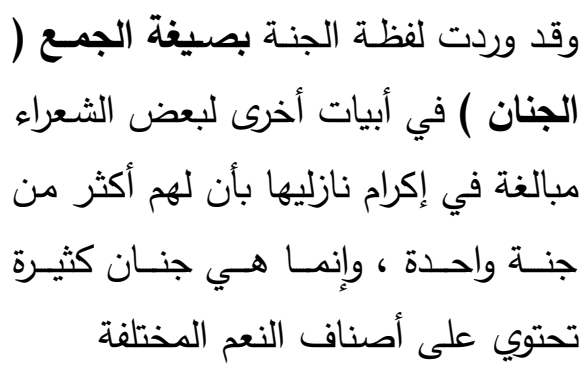 \\
\hline
\end{tabular}

(1) ديوان ابن الآبارالبلنسي ، ت(701)هـ ، تحقيق: د. عبد السـلام الهراس ، ص99 ؛ ، كتاب في الأدب الأندلسي

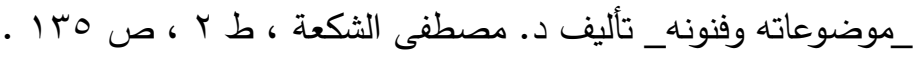

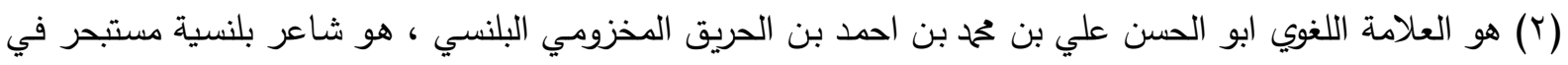

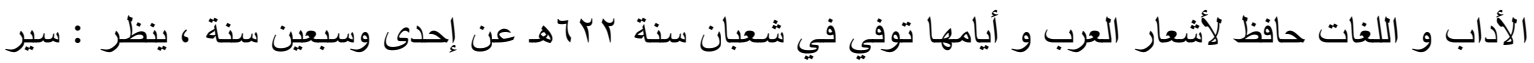

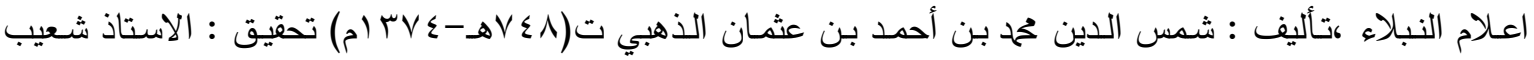

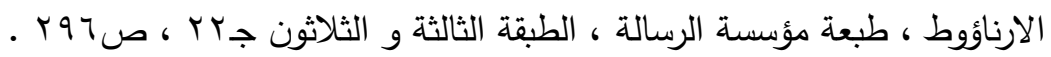

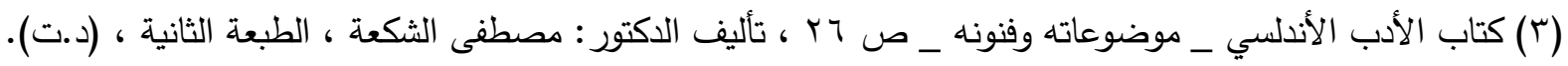
(ء) أبو بكر بن حُبيش ، هو أبو بكر محمد بن الحسن بن يوسف ، أصله أندلسي من مرسية وبها نشأ ، كان شاعراً مجيداً

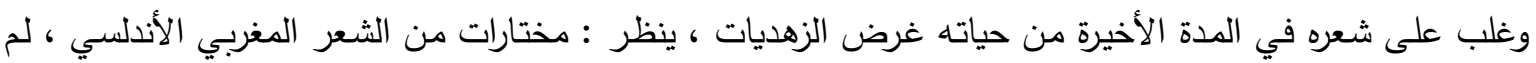

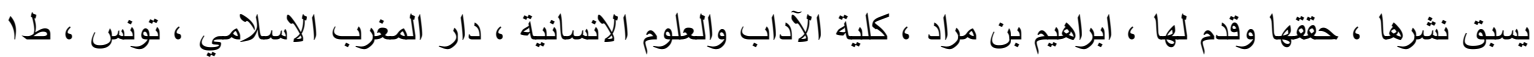
،

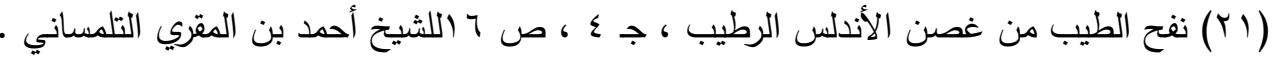




\begin{tabular}{|c|c|c|}
\hline الثاهد الشعري & اسم الشاعر & اسم الجنة \\
\hline أرى أتني به النار في صورة & 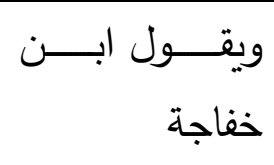 & الجنة : بصيغة الجمع \\
\hline 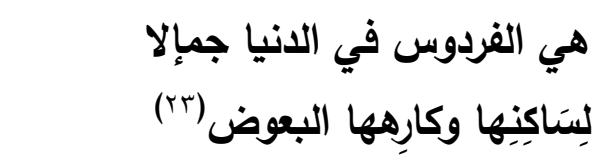 & سعدة الغرناطي جعــ بـن & الفردوس \\
\hline 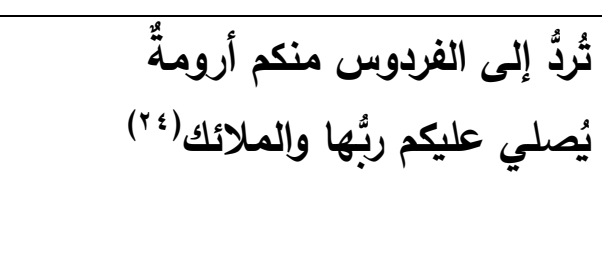 & 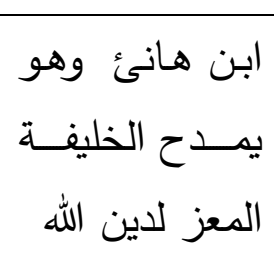 & \\
\hline 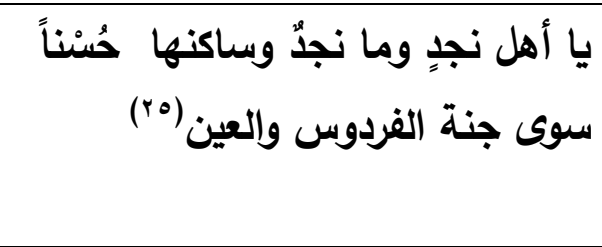 & 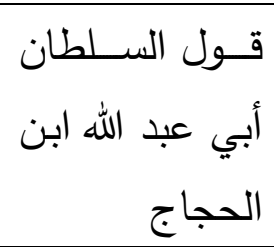 & مفردة الفردوس مضافة إلى الجنة \\
\hline 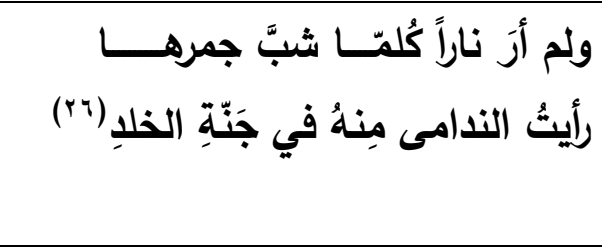 & 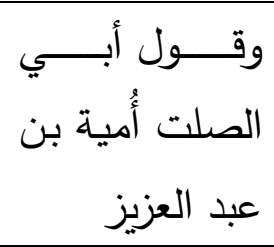 & الخلد \\
\hline والكوثر العذب زقِّماً وغسلينا أُبلنا بسدرتها & قول ابن زيدون: & الخلا مضافة إلى الجنة \\
\hline ثَكلتُك شمساً من وراءِ غَمامةٍة & ابن هانئ & بلفظة ( الجنة ) مضافة إلى (الخلد ) \\
\hline
\end{tabular}

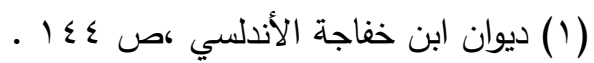

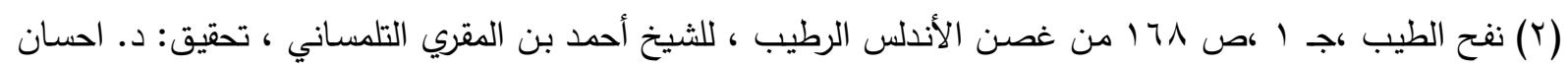

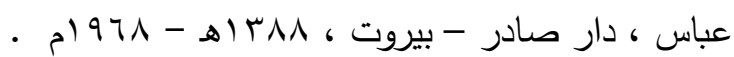

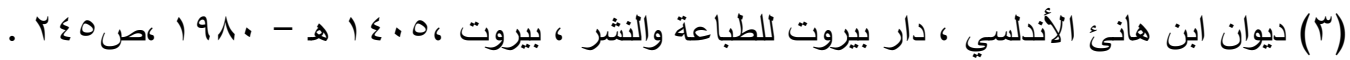

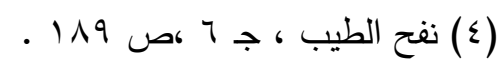

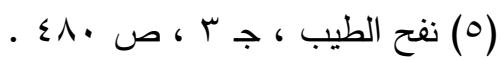

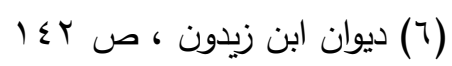

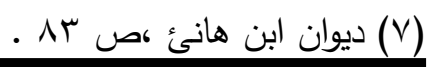




\begin{tabular}{|c|c|c|}
\hline الثاهد الشعري & اسم الشاعر & اسم الجنة \\
\hline 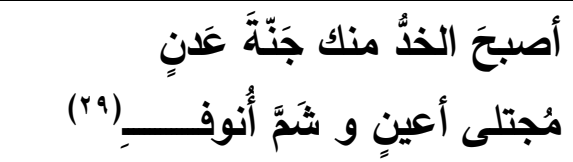 & 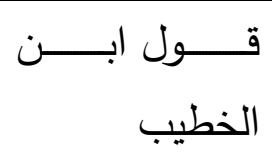 & عدن \\
\hline بوَأتني نُعماك جَنّةَ عَدْنٍ & قول ابن زيدون & لفظـة ( الجنــة ) مفـردة مضــافة إلـى \\
\hline 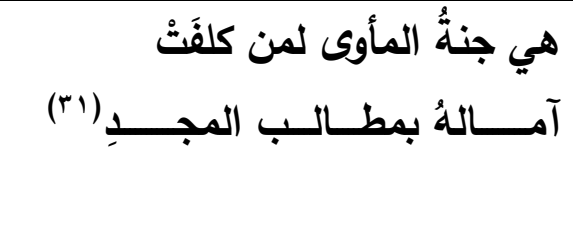 & 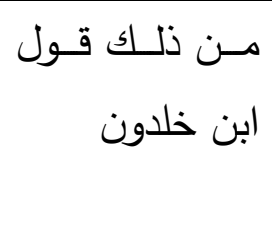 & 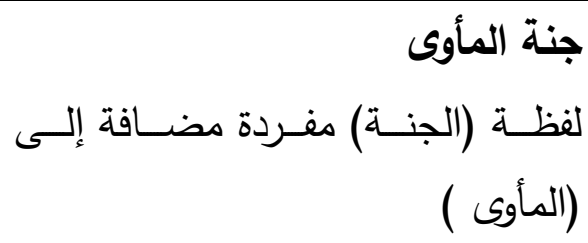 \\
\hline مضت جنّة المأوى وجاءت جهاء أشقى بعدما كنت أنعم(r) & 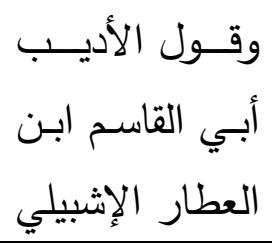 & \\
\hline 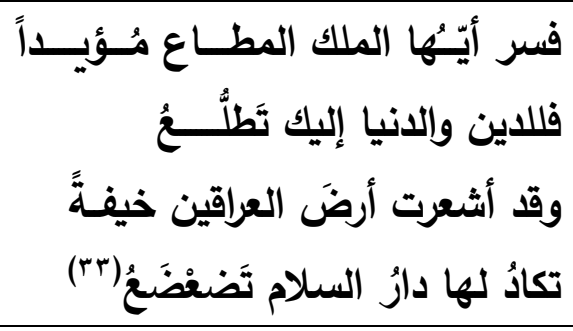 & قول الشاعر ابن & دار الــســلام \\
\hline 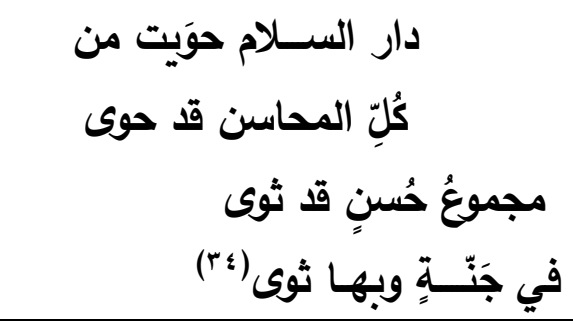 & البــــن ســــــيد & \\
\hline
\end{tabular}

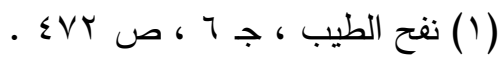

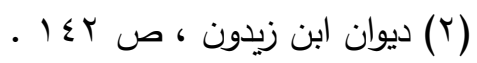

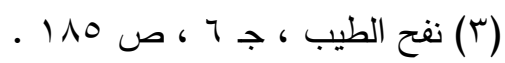

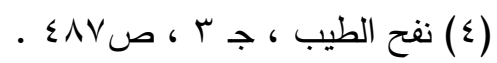

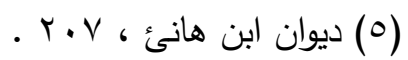

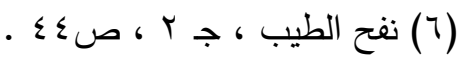


قمم الجبال والتلال يتضورون جوعاً للهجوم على هذه البلدة وإقلال راحتها ومسح جمالها . وقد وردت لفظـة الجنـة بصيغة الجمع ( الجنـان ) في أبيات أخرى لبعض الشعراء مبالغة في إكرام نازليها بأن لهم أكثر من جنة واحدة ، وإنما هي جنان كثيرة تحتوي على أصناف النعم المختلفة ، من ذلك قول أبي بكر بن حبيش صَوْمي مقبولِ وبرهأنه

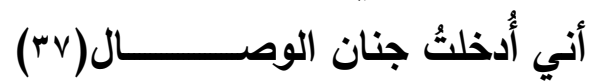
فإذا أخلص المؤمن وجهه لله تعالى وعمل بتعاليمه ولم يقصر في أي عمل فأنه يصبح مطمئن البال،

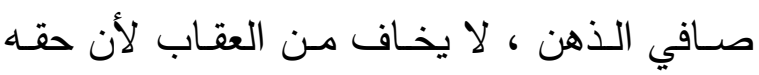
محفوظ وهو دخولـه لذلك المكـان الجميـل فتطير روحه طرباً وروعة ، ويستمتع بكل لحظة ولا يخلد إلى النوم لأنـه يريـــ أن يمتع ناظربـهـ بأطول مدة ممكنة . ويقول ابن خفاجة : أتتني به النار في صورة

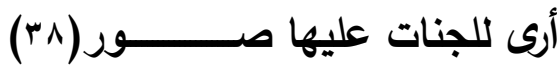
يذكر ابن خفاجة ما حل ببعض المدن الأندلسية

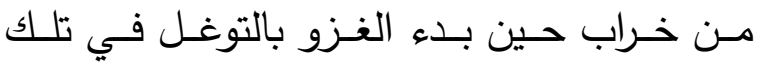
الأرض الطيبة الجميلة وأصبحت النيران الصغراء

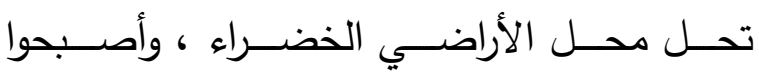
يتحسرون على ذلك الجمـال الذي ذهب ، حتى لارتى

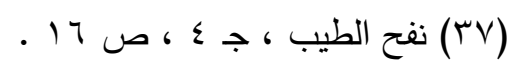

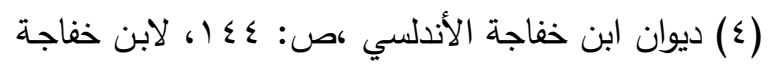

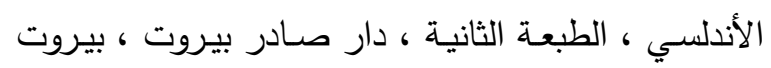

من خلال الجدول السابق يتضح لنا أن كل شاعر وظف أسماء الجنة في أغراضهم الثعرية فهذا ابن الإبار نلاحظ في بيته الشعري و جنةٍ حلّ أهلُ النارِ ساحتهــا

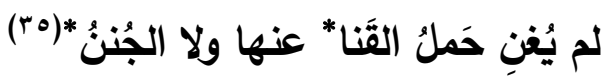
أنسه يمـزج بـين البكـاء والـذكريات العبقـة ، فهـو يصور حال مدينته التي من جمالها شبهها بالجنة، لكـن هـذه المدينــة الجميلـة قـد أصـابها الخـراب والـدمار ، ولعـل مـن احتلهـا وأشـعل النيـران فيهـا أقرب إلى أهلها ممن سعوا للوصول إلى كل ماهو جميل واتلافه والقضاء عليه بطريقتهم الخاصة . ويقول أبو الحسن بن الحريق

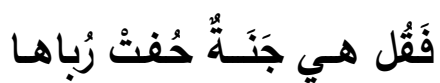

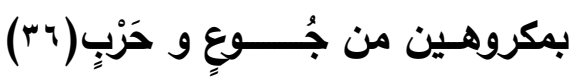

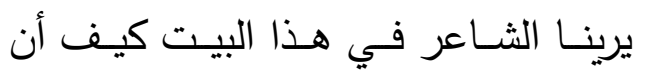

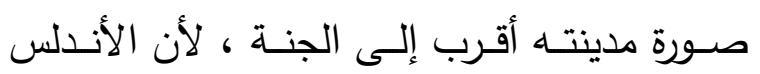
كانـت جنــة الأرض مـن حسنها وروعتهـا ، فجنـة

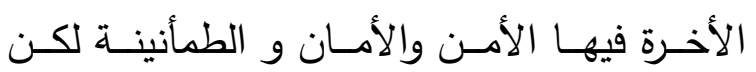

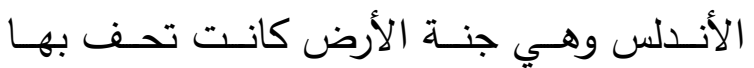
المخاطر من كل الجهات ، فالأعداء كانوا على (1) ديـوان ابن الآبارالبلنسي ، ت(701)هـ ، تحقيق: د.

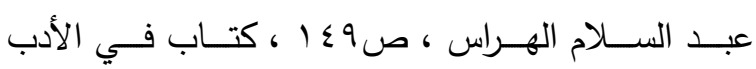

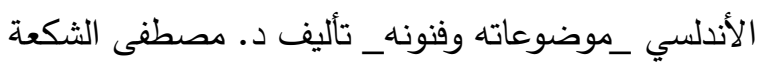

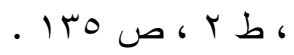

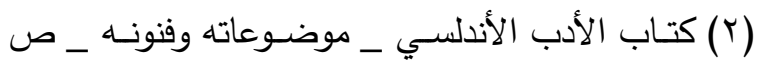
. r7 
بالأمـان والاطمئنـان تتنقل مـن مكان إلى مكان

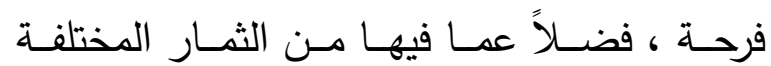
الألوان والأشكال والطعم ، كل هذا الوصف وغن الثيره

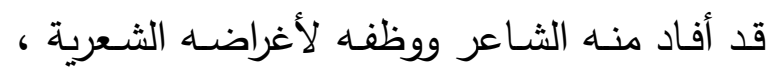

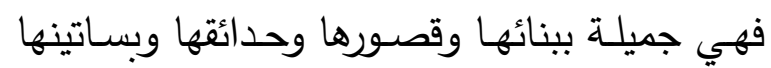

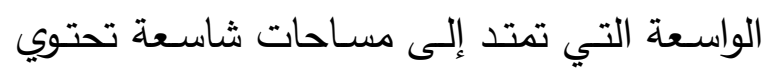

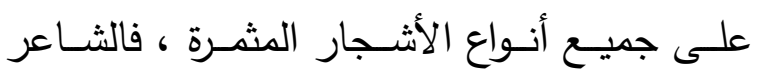

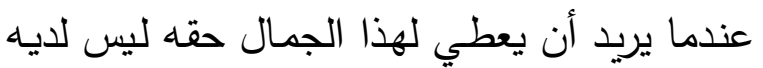
إلا تشبيه واحد آلا وهو تثبيهه بالفردوس ، لأنـه

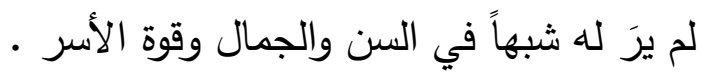

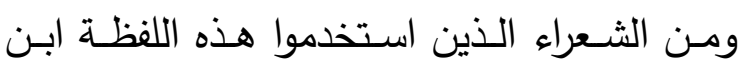

هانئ وهو يمدح الخليفة المعز لدين الله :

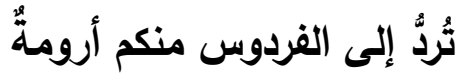

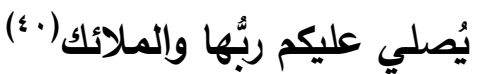

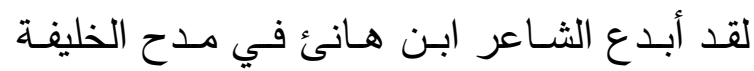

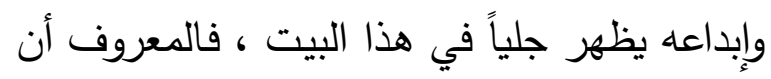

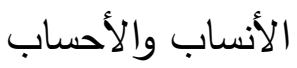
موجودة في الدنيا وأن الناس يتباهون في الحسب الابب

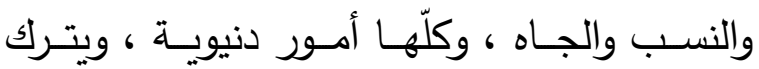
الإنسان تفكيره بالأخرة ، ولا يعرف أنه سوف يترك

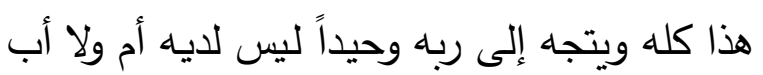

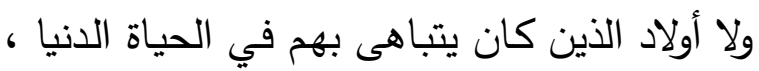
حتى إن التقى بهم في الجنة فسوف يشعر أن أن الله

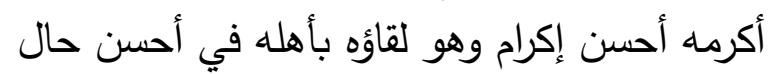

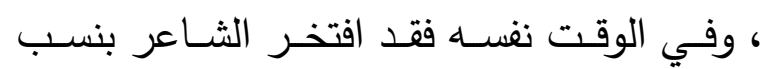

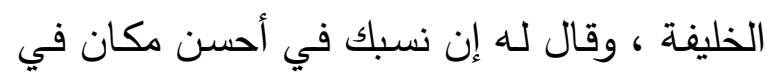

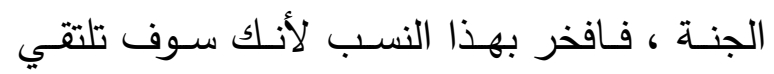
هناك بالأنبياء والصالحين وحولك أهلك ومحبـوك

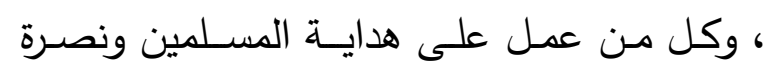

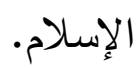

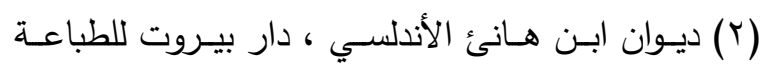

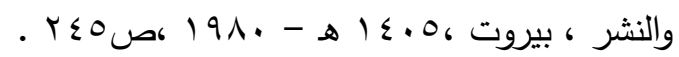

أضـحت صـورة الأرض الجميلـة في لهـب تلـك

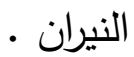

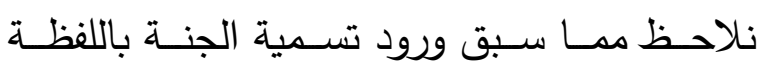
المفردة ، وبجمع التكسير (جنان) وبجميع المؤنث السالم (جنات) ولم تأت بصيغة المثنى (جنتان) ويعود السبب في ذلك إلى أن الثـعراء يتمنسون

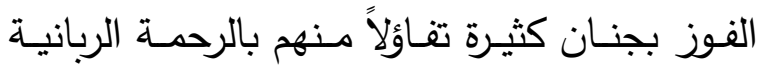

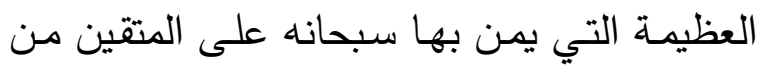

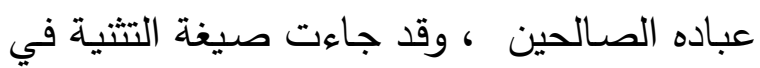
القرآن الكريم فقط ، ولم تأت في الثعر والسبب الهب

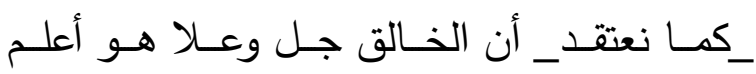

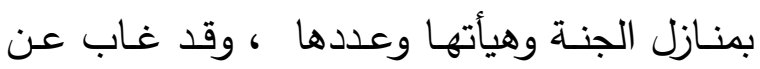

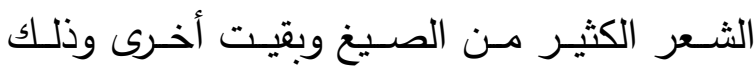

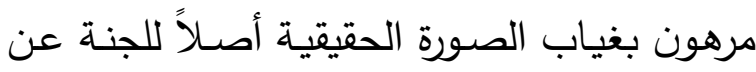

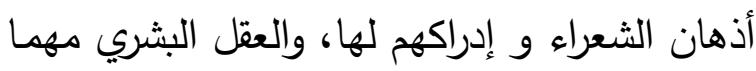
بلغ يبقى قاصراً في معرفة صورتها وإدراك ماهيتها

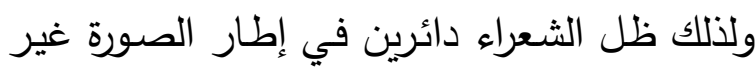

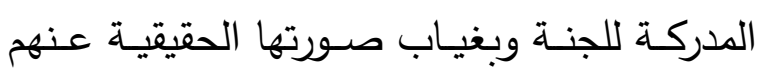
تغيب بعض صيغها ولم يبق لهم منها سوى تلك

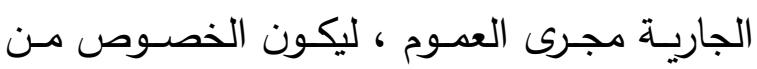
الأمور المرتبطة بذات الله التي لا يشاركه بها أحس الحد

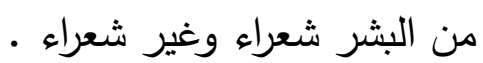
وممـن ذكـروا (الفـردوس) مشبهاً بهاء (بلنسـية) الثاعر أبو جعفر بن سعدة الغرناطي الفردي الغيا هي الفردوس في الانيا جمالاً

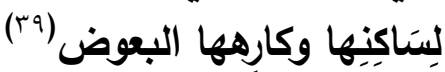

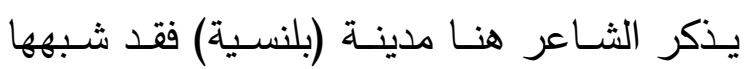

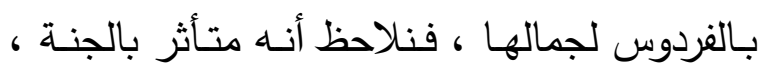

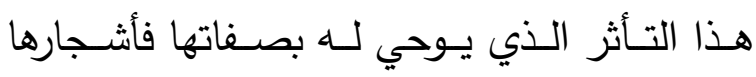
الكثيفة التي لها ظل وارف وكثيف يمتد هذا الظل

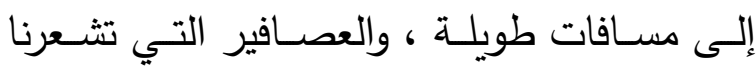
(1) نفح الطيب ،ج ( ،ص 141 . . 
كان جنـة بالنسبة لهم ، وهـ يتخيلـون أنفسهم ،

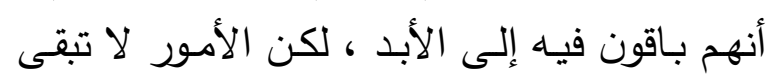

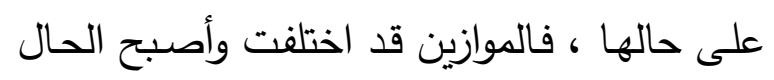

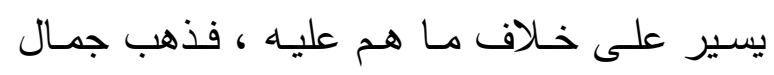

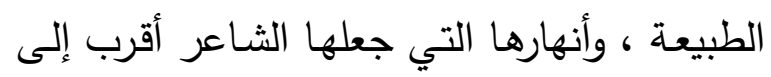
نهر الكوثر الذي هو نهر في الجنة قد قل ماؤه ،

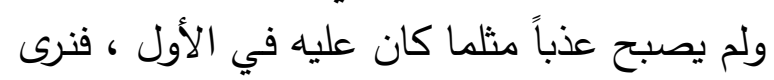
أن الثـاعر قد استخدم كثيراً من المفردات الدينية من القرآن الكريم والسنة النبوية الثريفة وربط بينها وبين الواقع الذي يعيشون فيه .

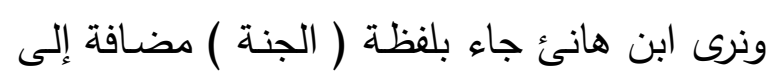
( الخلد ) في مدح القائد جوهر ، وهو يقول: ثكلثُك شمساً من وراءِ غمامةٍ

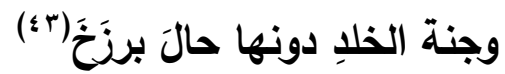

إن الثاعر في مدحه للقائد قد شبهه بالشمس التي

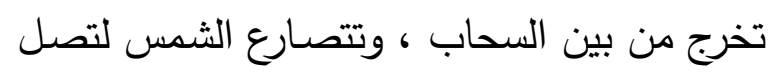

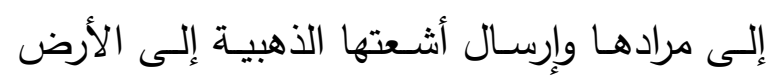

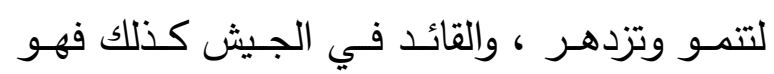

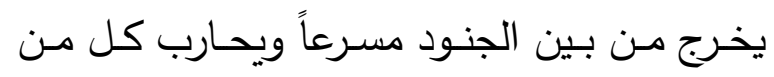
يتصدى لله ليصل إلى غاياته التي سعى من أجلها

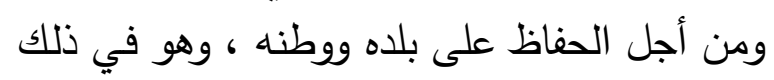

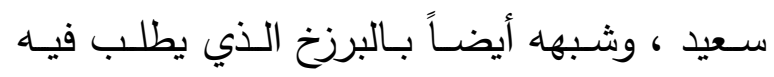

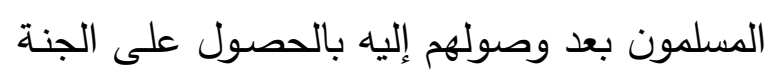

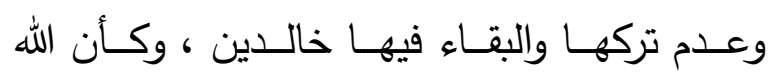
استجاب لهم ذلك لأن دعوة المؤمن لا ترد .

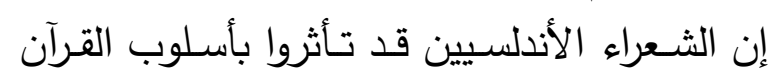

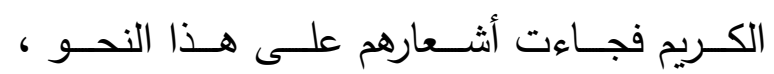
وينظمون على وفق الألفاظ التي يريدون أن يستقوا منها صورهم الشعرية ، وقد وردت لفظة الأفية ( الجنة ) مفردة مضـافة إلى (عدن ) أو ترد أحيانـاً بلفظـة التها
وقـد أورد الثـعراء مفـردة الفـردوس مضــافة إلـى لـ في

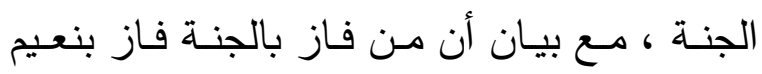

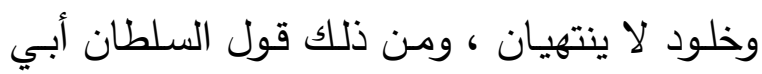
عبد الله ابن الحجاج يا أهل نجدٍ وما نجدٌ وساكنها حُسْنا

سوى جنة الفردوس والعين (1؛) فقد جمع الثاعر بين الفردوس والجنة ، ووصف جله نجد و أهلها ، وإن أهل نجد يمتعون أبصارهم بهذه المناظر فهي شبيهة بالجنة في مناظرها وحدائقها

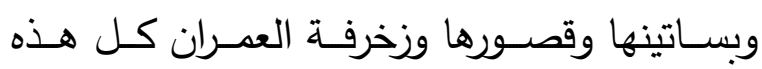

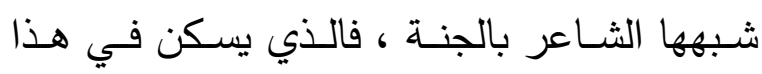

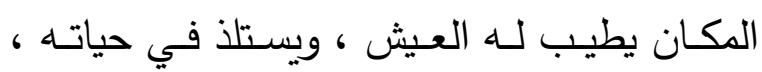
وعليه أن لا ييتعد كثيراً عن ذكر الله ، وإنما عليه أن يتذكر هذا الجمـال أن هنـالك أكثر منـه جمـالاً في انتظاره. ووردت تسمية الجنة في القرآن الكريم مرتبطة بـ التطاره ( جنة الخلد ) دلالة على أنّ من يدخلها يخلد فيها

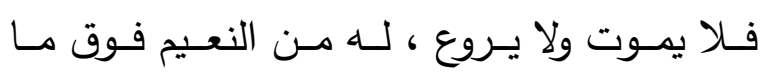
ونلاحظ ذلك جلياً في قول ابن زيدون: يا جنة الخلِ أُبدلنا بسدرتها

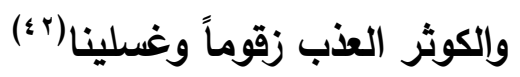

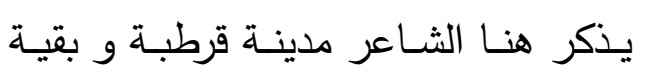

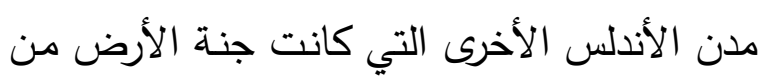

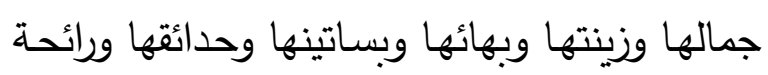

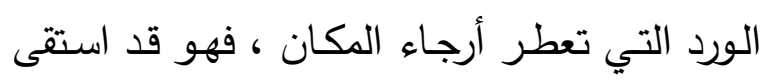
من القرآن الكريم لفظة ( جنة الخلد ) لأن مكانهم

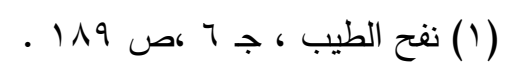

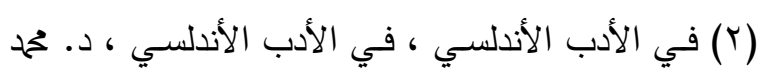

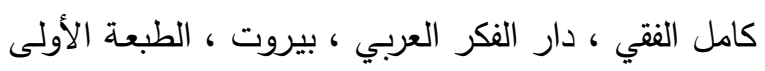
م) 980 . . 
يصف ذلك المكان بكلمة واحدة مخصوصسة وهي

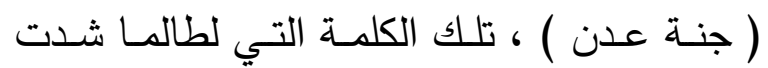
المسلمين الأوائل عندما كان الرسول ( صلـى الله عليه وسلم ) يتحدث عنها ، فكان خيالهم يسرح

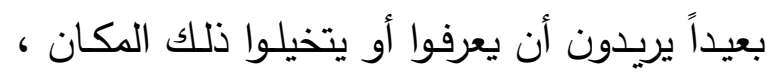

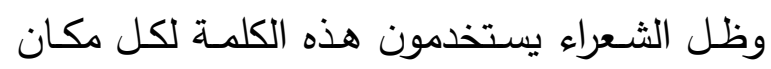
يسحرهم ويجذب النفس إليه وترتاح وتطمئن لـه ،

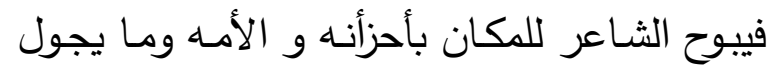
في نفسه ، فيكلم كل ما حواليه من الطبيعة فترتاح

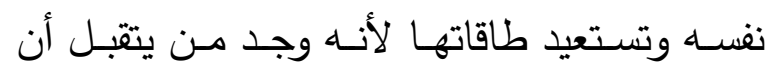
يستمع إليه . جنة المأوى وهي من أسماء الجنة التي وردت في

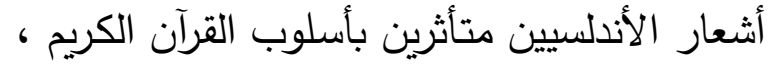
ووردت لفظة (الجنة) مفردة مضافة إلى ( المأوى) ، من ذلك قول ابن خلدون: هي جنةُالمأوى لمن كلفَتْ

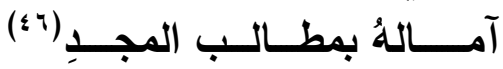

فالذي يريــ أن يصـل إلى مبتغـاه ويطلب المجد

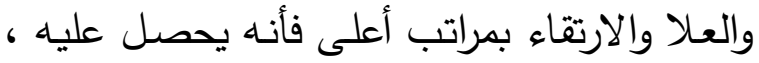
ومن يريد أن يذهب إلى الجنة ويبقى فيها فعليه أن

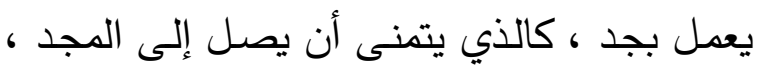
لأنه من شيم الرجال ذوي الأمال الكبيرة والعظيمة. دار السـلام من أسماء الجنـة ، ووردت في القرآن

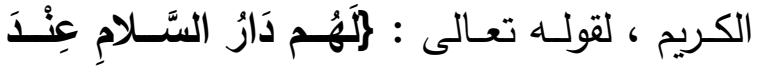

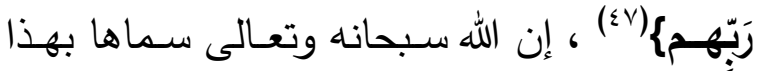

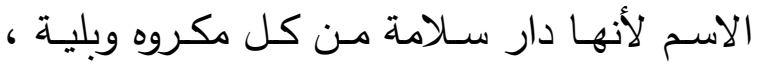
تصيب الإنسـان ، وهي دار الله ، ومن أسماء الله لأن

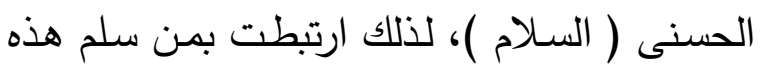

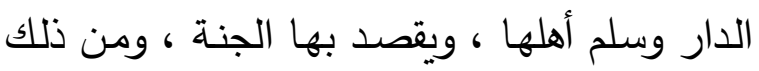
قول الثاعر ابن هانئ :
(جنـات ) مضـافة إلىى (عـدن ) ، فمـن ورودهـا بلفظة مفردة قول ابن الخطيب :

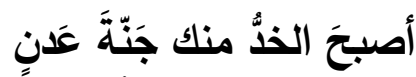

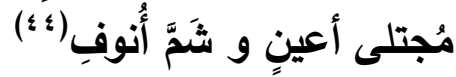

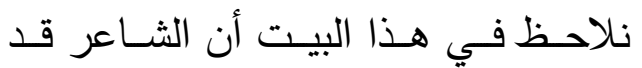
استعمل جنة عدن في غرض الغزل بأسلوب أقرب إلى النزعة الدينية ، فتشبيه الخد بجنة عدن أقرب

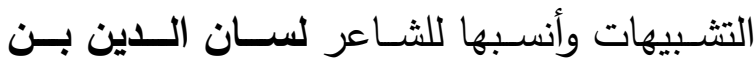
الخطيب ، فهذا الخد من جماله وحسنه فأنه يسرق الأبصار إليه والتمتع فيه والنظر إليه ، متجاهلين مـا حولهم ، فهذا يعطينـا صسورة قرببة إلى الجنـة وجمالها ، فهي تسحر الأنظار ، ويبقى الإنسـان

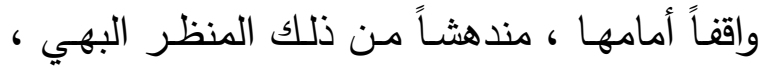
فالثـاعر مهمـا حساول أن يصـف فهـو لا يعطي امسي حقها الكامل في حسنها وجمالها ، وجنة عدن هي

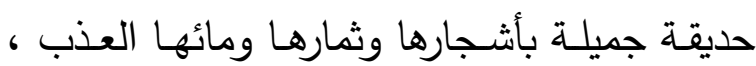
وخد المرأة الحسناء ليس فيه هذه الصفات وإنما ولئها

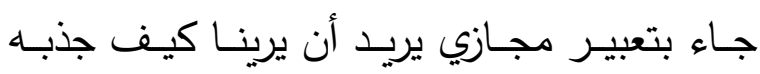
حلاوة هذا الخد في حسنه وبهائه فعجز لسأنه عن ين يلن

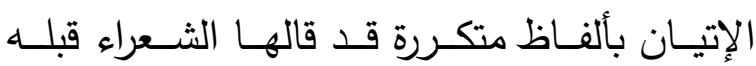
فاختصر الألفاظ وألوان الكلام وجاء بلفظة شاملة وموحية لهذا الجمال وهي لفظة ( جنة عدن ) . ومـن الثـعراء الذين استعملوا لفظـة ( الجنـة )

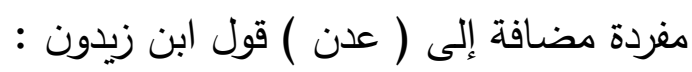
بوَّأتني نُعماك جَنّةَة عَدْنِ

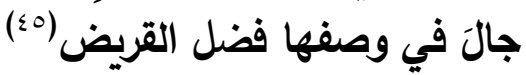
يخاطب ابن زيلدون المعتضد بالله ويشكره على إتاحتـه لـه بـأن يتــزه في حدائقـه وبسـاتينه فأصبح ابن زيدون يجول في ذلك المكان وعيناه

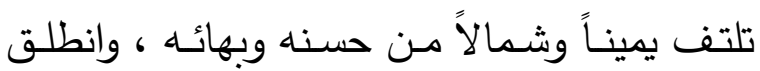

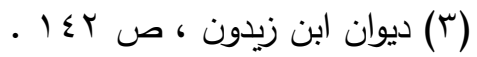




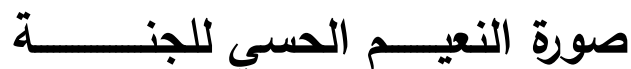

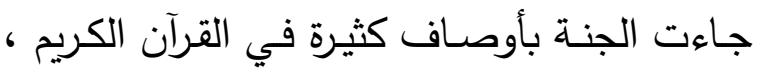

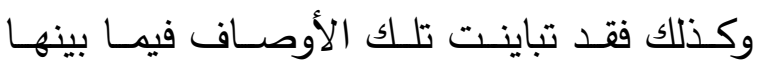

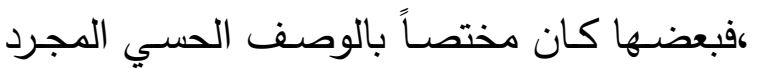

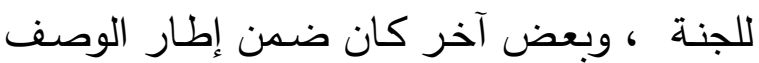

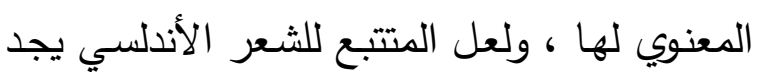

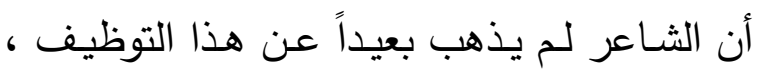

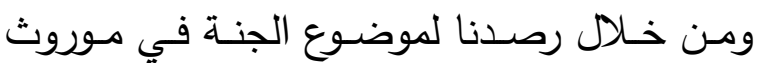

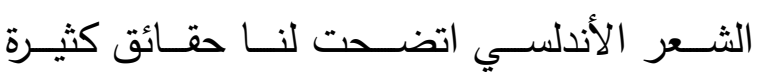

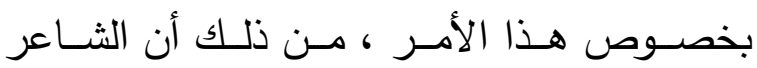

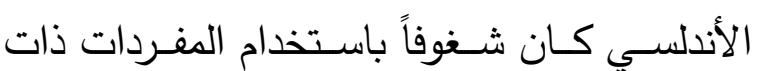

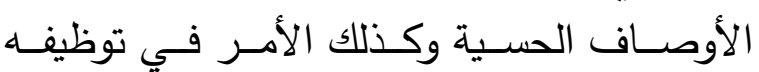
للمفردات غير الحسية ، ومن هنا فقد وردت الجنة

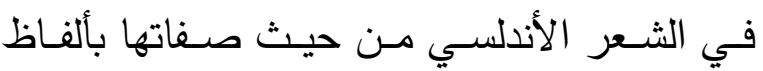

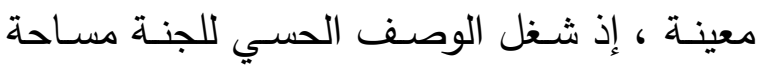

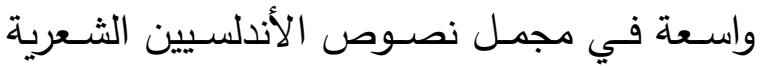

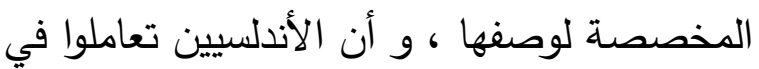

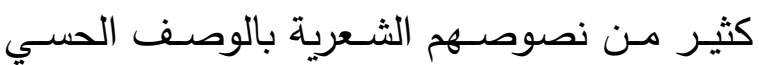

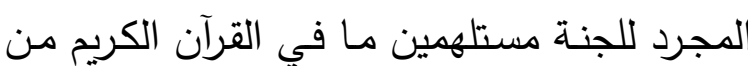
صور ومواد حسية كانت المادة الرئيسة للثـعراء

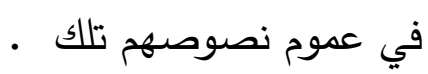

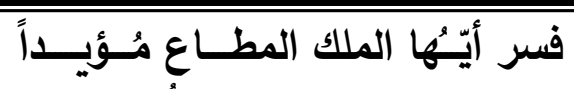

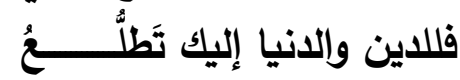
وقد أثعرت أرضَ العراقيين خيفــــــةً

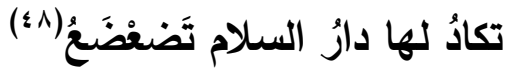
في هذا البيت يمدح الثاعر القائد جوهراً ، ويذكر مسيرته التي خرج من أجلها إلى البلدان لئل

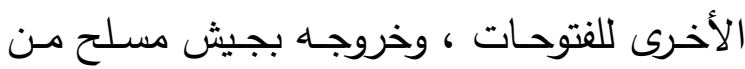
كل الجوانب ، فعند النظر إليه نرى الهيبة والقوة لإن

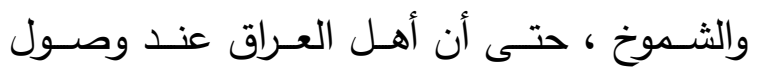
الجيش إليهم نظروا مذهولين إليه ،إن دار السلام العـام

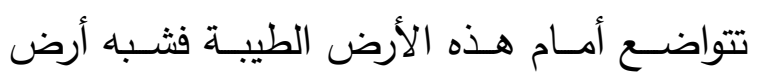
بغداد بدار السلام لحسنها وجمالها وسلامتها من الأن

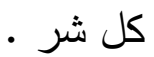

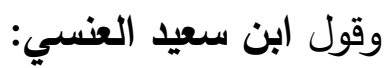
دار السـلام حوَيت من العندئ

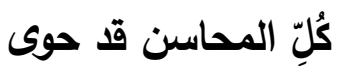

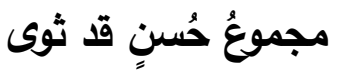

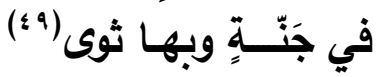

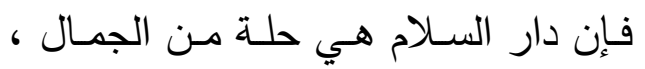

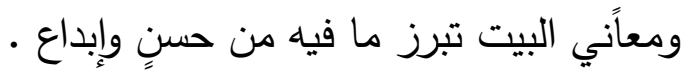

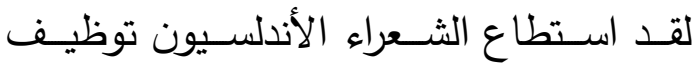

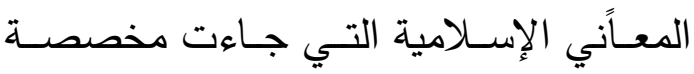
لوصف الجنة فأبدعوا في تسجيل صورة رائعة

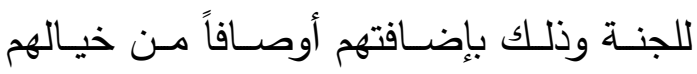
الخصب مدا سـاعد على إبراز شعرهم .وإن إنـان

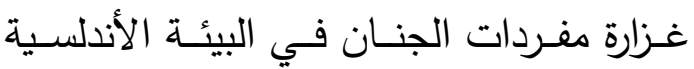

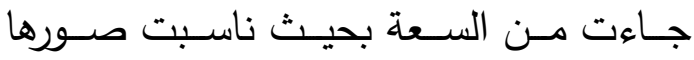

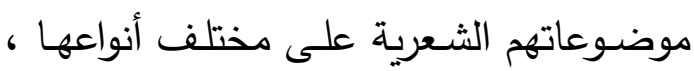
من غزل ورثاء وفخر ومدح وغير ذلك . 


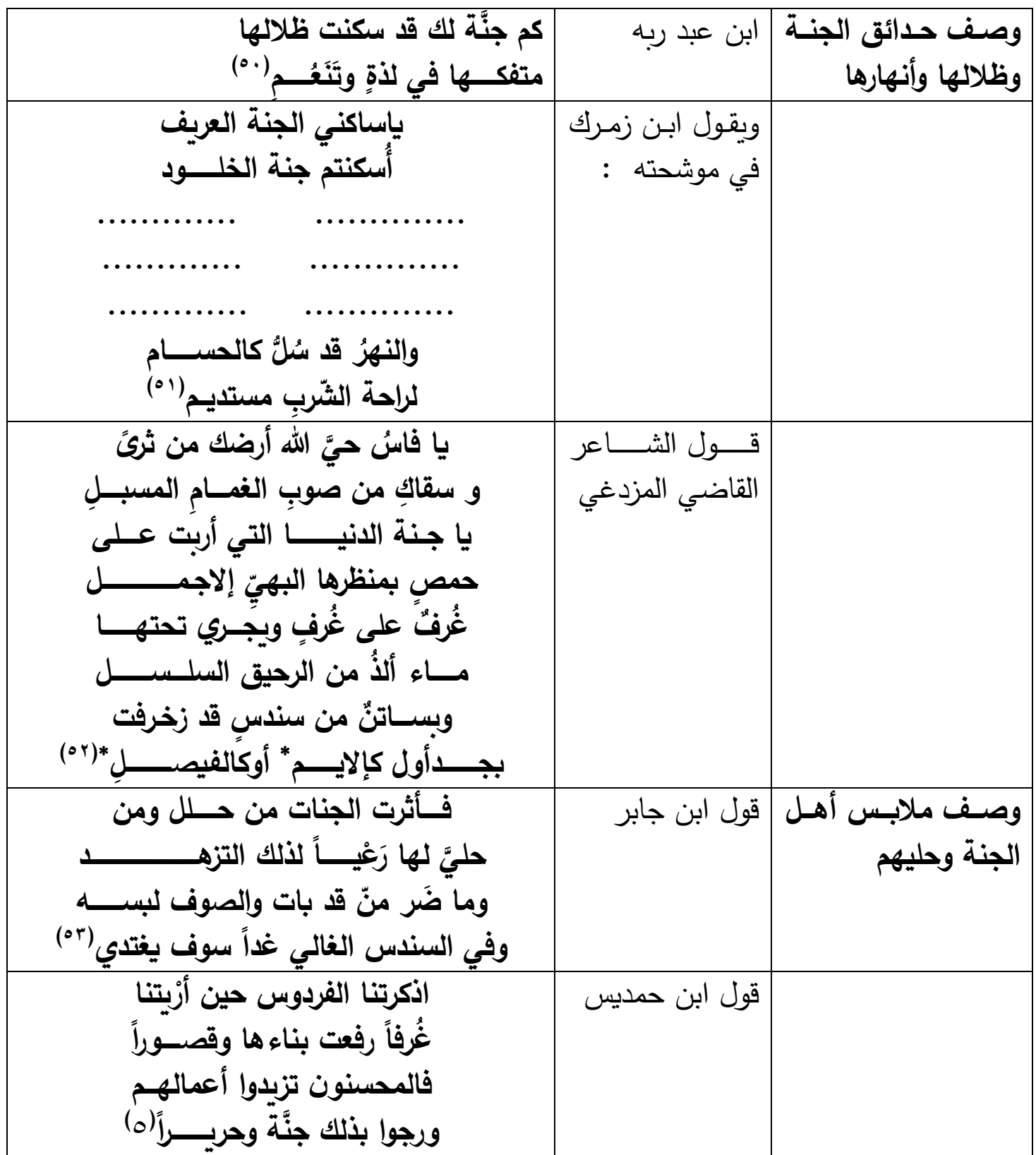

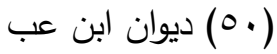

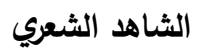

اسم الثاعر

الوصف الحسي لنعيم الجنة

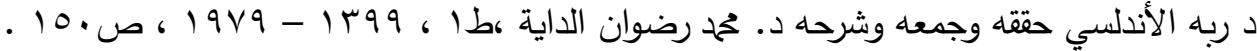

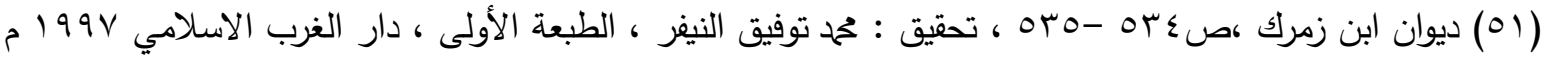

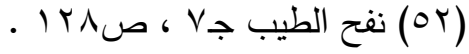

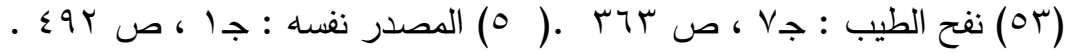


جعلوهـا ســلة الـدخول إلـى العقـول بمجـرد مـن قراءتها و تحبيب المكان من خـلال التحدث عنـه

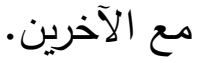
و نلاحـظ أن ابــن زمـــك كـان مـن المتـــثرين بالطبيعة الأندلسية وتثبيهها بالجنة ، فالذي يسكن في مكان حسن المنظر ،عليل الهواء، فكأنـه قد أقام فيه وأخلد إلى الأبد ، لأنه يعطي راحة نفسية إلى القلب ، وتطيب الجسم ولاسيما إذا وجد في مثل تلك الأماكن ، ومن هنا تنفتح أسارير الشعراء وتتوقد قرائحهم بقول الثعر وكأنّ المكان يزودهم بالكلمـات و أوراق الثـجر تســاعدهم علـى نظــم الثعر ، أما النهر الجاري فأقرب إلى الحبر الذي يكتبون فيه فيكف ولا يبدع الثاعر في القول وهو في مكان كهذا فكأنـه يخلد فيه ويسعد إلى الأبد وعندما ينظر إلى أي جهة فيه ينشرح صدره من حسـنه وجمالـه ولا يكتمـل جمالــه إلا إذا طوقتهـهـ السعادة والسـلامة والأمـان ، ويذكر الشاعر الجبل العظيم الشامخ الذي يكون مغطى بوشاح أخضر يزينـه ، وهذا الجبل يعطي وقاراً وهيبةً ، ويتخلل المكان الجميل نهر كأنه حافة السيف الحاد وذلك ما يشير إلى جمال الصورة ، إذ أن حافة السيف تكون لامعة ، ومن شدة لمعانها فأنها تكون مثل المرآة تعكس الأشياء ، وأقرب صورة للشاعر وهو يوضح لنا مثل هذه الفكرة هو النهر لأنه لا يوجد شـيء في البستان يعكس لنـا صـورة الأشياء إلا النهر الصـافي الذي يخترق الأرض بنقائهه و لا لاءل تشـوبه أيـة شـائبة ،فهو دائم الجربـان مستعد لأن يسقي أي شخص ظمآن دون مقابل ، فهو يعطينا

\section{الجدول على سبيل المثال لا الحصر} فلقد ذكرت الآيـات القرآنيـة أن في الجنـة حدائق غنــاء ، وبسـاتين كبيـرة وعظيمـة ، تتميـز بظلهـا الوارف ، وخضارها الدائم وهوائها المعتدل ، وأهلها يتمتعون بهذا الجمال بالحدائق وظلالها وأشجارها ، وفي الحقيقة وصف القرآن الكريم حدائق الجنة وذكرها بأوصاف يمكن للحواس البشرية أن تدركها و أن يربطوا بين بيئة الجنة والبيئة التي يعيشون فيها في الدنيا ويعرفوا الغرق .

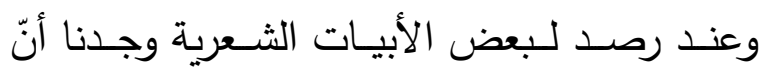
الشعراء قد أكثروا من وصف الحدائق على نحوِ لافت وذلك لجمال البيئة الأندلسية ومـا اشتهرت فيه من البساتين الخلابة ، والأنهار الرقراقة التي تجري فيها المياه بشكل ينساب انسياباً جميلاً بما في بيئتهم التي يعيشـون فيهـا ، إذ ذاك يعرفون الفرق فيما بينهما ولعل الأندلسيين قد شبهوا بيئتهم الطبيعية بالجنة وقـــ اسـتمدوا هــذا الوصـف مـن القـرآن الكـريم ،والسبب في ذلك أن البيئة الأندلسية قد توافرت فيها من الطبيعة ما أبدع الخالق صنعه ، فمناخها

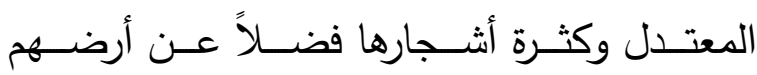
الخصبة التي ساعدت بشكل كبير على نمو مثل هذه الحدائق ، فكان الأندلسيون يتمتعون بظلال

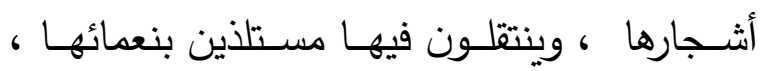
متخذين من هذه المنـاظر شبها في وصف جنة الأخرة و إن كانت تلك على غرار التخيل إلا أن الشعراء جعلوا وجهاً للمقاربة ، و قربوها إلى أذهان النـاس كي يستطيعوا تخيلها بسطوا الألفاظ ممـا 
مـن ذلك كلـه يتضـح أن الثعراء قد أفاضـوا في

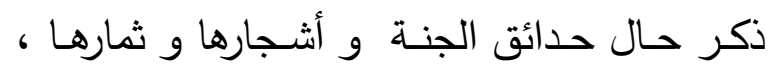

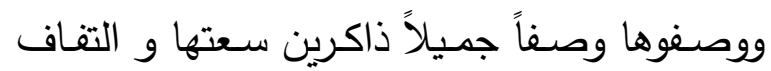

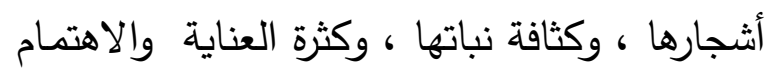

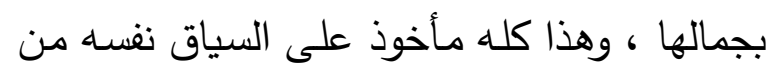
وصف الله سبحانه و تعالى لنعيم جنته و حدائقها

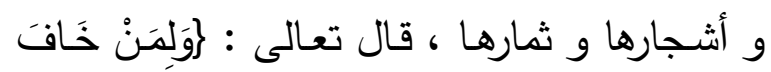

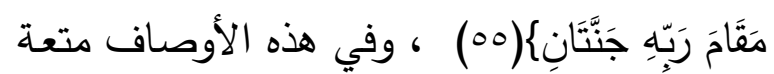

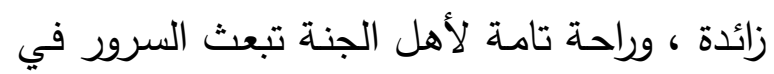

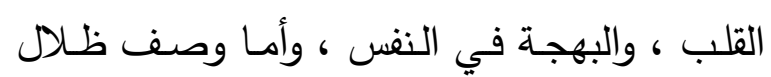

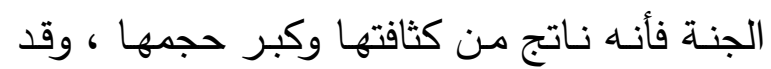
تخيل أغلب الشعراء صور الحدائق التي وردت في في

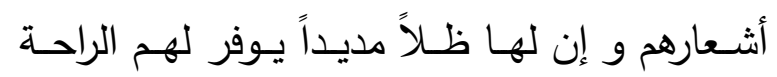

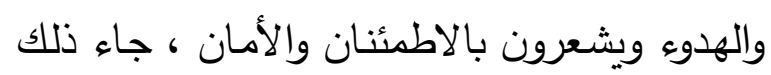
كله بوصف جاد و مؤثر ، وصف نابع من وعي

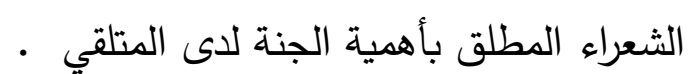

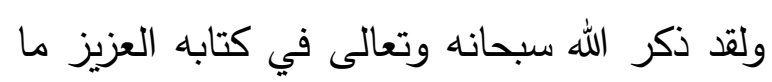

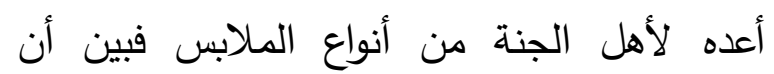
ملابس أهل الجنة تتكون من الإستبرق والحرير

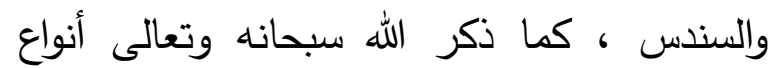

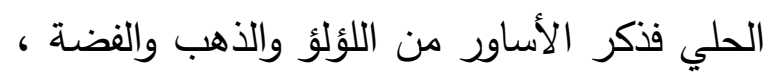

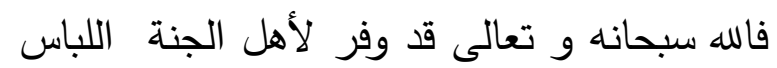
والزينة معاً ، فاللباس يدل على الجمال والوقاية

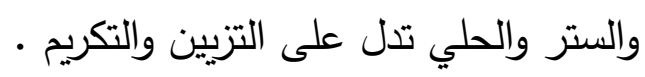

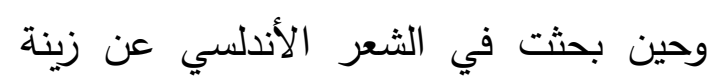
أهل الجنة ولباسهم وجدت أنها قليلة جداً ، وأن الثعراء لم يتعمقوا في هذا المجال من حيث ماهية
من مائه بكرم ،ويتدفق بشغف ليشبع كل من مدت يده إليهه ، ويسقي تلك الأرض الطيبة ، والزهور

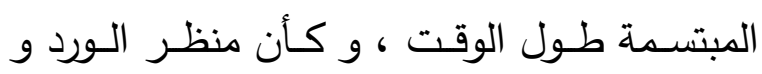

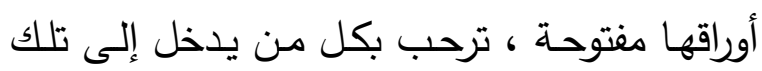

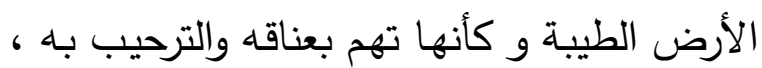

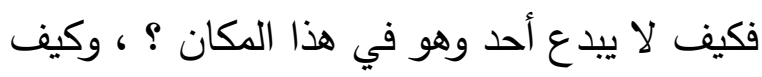

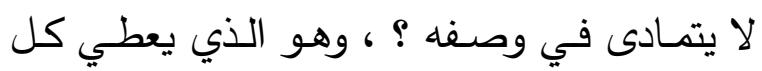

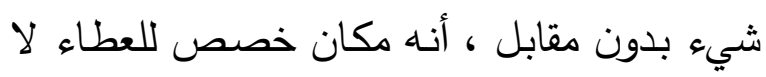

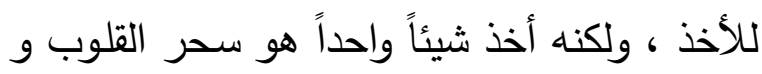

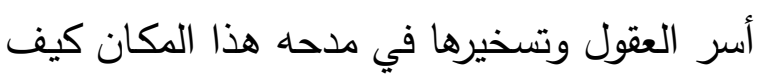

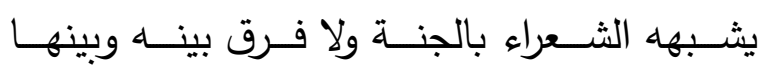
والمكانين من صنع الباري جل وعلاه. و قول الثـاعر القاضـي المزدغي: نتفق أن الله

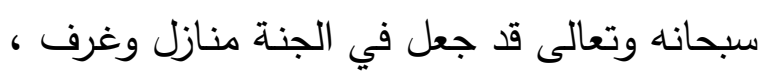

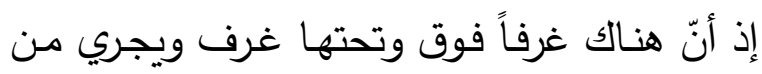
بين هذه الغرف النهر الذي شبهه الثاعر بالرحيق

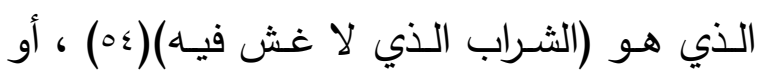

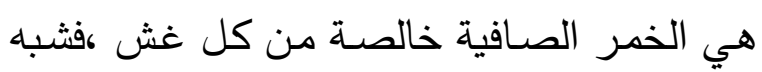
النهر بالرحيق لعذوبته وصفائه ونقائه ، وعندما

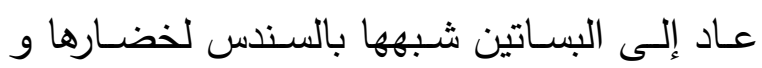

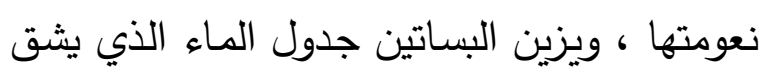

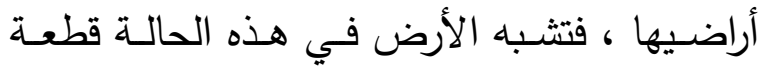

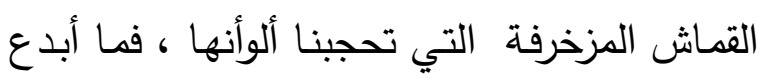

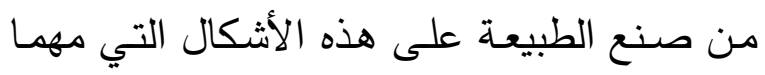

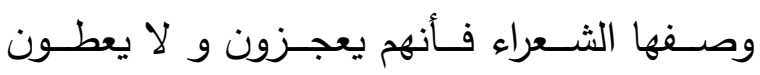
للطبيعة حقها الكامل من الجمال لغزارتها وكثافتها و خصوبتها ل 


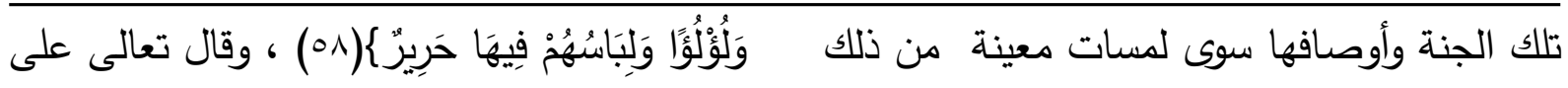

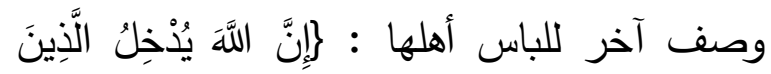

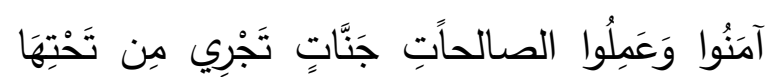

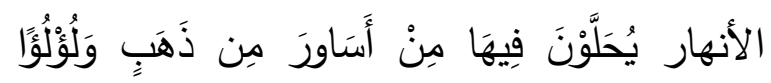

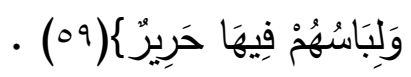
تبين أن الثـعراء قد أفادوا مـن القرآن الكريم في وصف ملابس أهل الجنـة وحليهم و استخدموها في أبياتهم وأضافوا إليها شيئاً من مخيلتهم مطلقين العنـان لها في وصف ملابس أهل الجنـة بصـور مشرقة وجميلة تتيح للقارئ أن يتمعن فيها ويقراها مرارا ليتزود من جمالها الفتان وصورها المشرقة ، فلينظـر الإنسـان مـا أعـده الله لـهـ مـن نعسيم في هي الأخرة، فالشعراء قد سلكوا مسلكاً قربياً إن لم نقل مشابها لذلك التوظيف في أشعارهم ، و قد نجحوا في ذلك ، وهذا ما نراه جلياً في دواوينهم الشعرية .

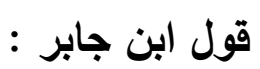
فـأثرت الجنات من حــلـل ومن

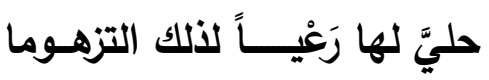
ضَر منّ قد بات والصوف لبســــهـ

وفي السندس الغالي غداً سوف يغتدي(هن) نلاحظ في هذا البيت صورة واضحة عن لباس أهل الجنة دن (سندس) و (حلل) أو (حلي) فالثاعر يبين أنّ الذي يزهد في دنياه ويفضل لباس الصوف ولا يستكثر لدنياه فأنه في الأخرة يلبس من السندس الذي هو لباس أهل الجنة . ويقول ابن حمديس: اذكرتنا الفردوس حين أزريتنا غُرفاً رفعت بناء ها وقصــــوراً فالمحسنون تزبدوا أعمالهـم ورجوا بذلك جنَّة وحربــــــاً (ov) فالثاعر وجه كلامه إلى الناس بشكل عام لفرل فالذي يعمل عملا صالحاً مخلصاً في عمله ويزيد عليه من دون تذمر فأنه يرجو وجهة واحدة يتوجه إليها هي دخول جنة عدن ، يلبس لباس أهلها المصنوع من الحرير الذي لا يلبسه إلا المترفون في الدنيا ، فالمسلم يريد لبس الأخرة التي لا عناء فيها ولا هم ، وقد جاء البيتان على أسلوب القرآن الكريم نفسه في وصف الجنة ، قال تعالى ذاكراً اللباس الذي سوف يتحلى به أهل الجنة : جَجَنَّاتُ

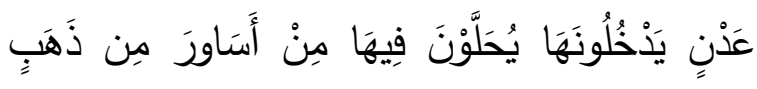




\begin{tabular}{|c|c|c|}
\hline الشاهد الشعري & اسم الشاعر & الوصف الحسي لنعيم \\
\hline 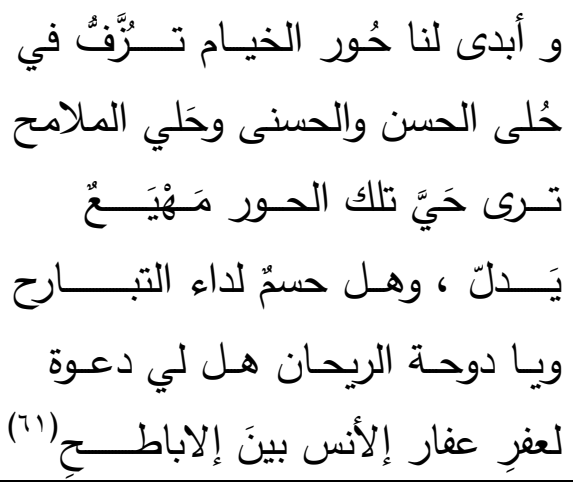 & قول ابن راجح(·r) & وصف نساء أهل الجنة \\
\hline 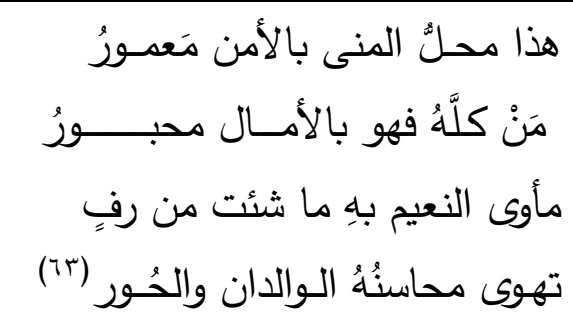 & قال ابن رضوان (זr) & \\
\hline
\end{tabular}

(1) هو محم بن علي ابن الحسن بن راجح ، الثريف الحسني ، أبو عبد الله يعرف بابن راجح ،صاحب رواء وأبهة ، توفي

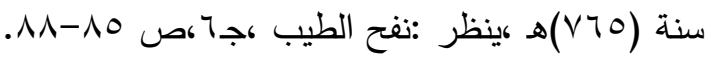

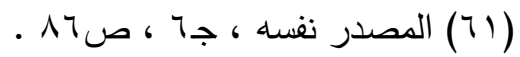

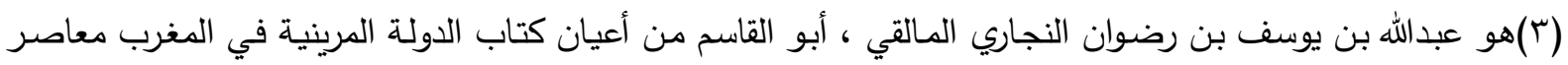

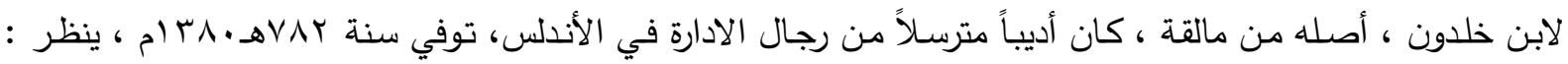

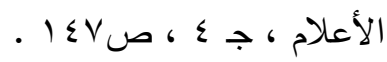
(ז7) المصدرالسابق ، ج7 ، صله 9 • . . 
جمالها بتشبيههن بحور الجنة والفرق بينهن عظيم

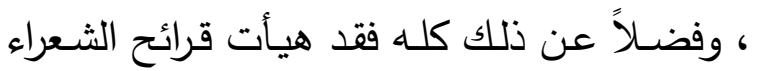
الأندلسيين لصـور الجنـة ومـا فيها من الأوصـاف ما لم يرد في القرآن الكريم ، وهو ما نعده إضافات

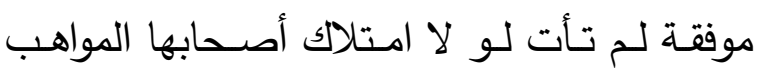
الفذة ، والقدرة على الاستتباط والتخيل والتأمل . صورة النعيم المعنوي والروحي للجنة لقد خلق الله الإنسان من جسد و روح ، و جعله بفرته يتمتع بالمتاع الروحي والمادي معاً ، على هلى الرغم من أهمية المتع المادية للإنسان كالمأكل والمشرب و المسكن ، لكن لا يستطيع أن يسعد بذلك دون وجود الراحة النفسية ليستلذ و يأنس بهذه الملذات ، إن الإنسان بفطرته التي خلقه الله بها لا يكتفي براحة الجسد فقط دون راحة البال معه ، و إن حصل نقص في الراحة الجسدية أو

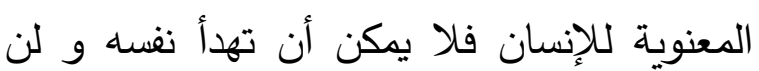
يصلح باله ، و قد سبق أن لاحظنا كيف وردت صفات الجنة الحسية والمادية في القرآن الكريم إذ ذكرت الآيات القرآنية الصفات التي تجمع بين أنواع النعيم التي تلبي ما ترغب عليه فطرة الإنسان ، فوجدناها تصف طعام أهل الجنة و

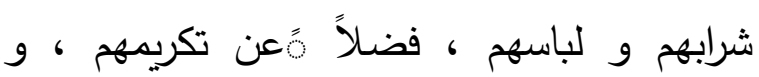
الحفاوة بهم ، و الرضا من الله سبحانه و تعالى والآيات التي تصف نظرة وجوههم و إشراقها و استبشارها . فضلاً عن أن هناك أنواعاً أخرى للنعيم الروحي لا يمكن لأحد أن يعرفها أو يتكهن

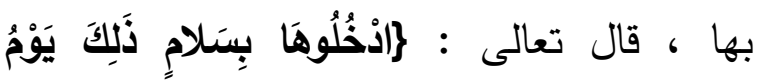

لقد استخدم الشـاعر لفظة (الحور) أكثر من مرة فهو شبه النساء اللاتي في الخيام بالحور لجمالهن

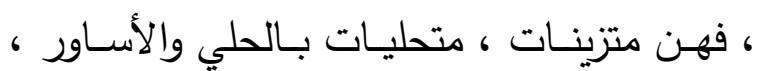
فمن نظر إليهن خطـر في بالـه حـور الجنـان ، فالثـاعر قـد اسـتخدم مـا في الجنـة في وصـفه وسخرها في شعره ، وقد ذكر (الريحان) الذي هو نبات له رائحة زكية ، فعندما يهب الهواء على هذا النبـات يطيب الجـو ، وتتفتح الـنفس لمثل هـذه الروائح ، فكيف لا يستغل الإنسان وقته ويستثره في غـرس الأعمـال الطيبـة والصـالحة وهـو يقـرأ القرآن الكريم ويقرأ مثل هذه الأبيـات التي فيها

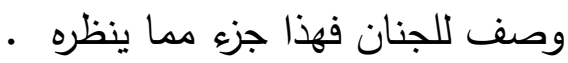
وإذا حل الإنسـان بذلك المكان الجميل الذي أعده الله له فهو تحيطه السعادة و الطمأنينة والسلامة و الأمان وتلازمه السعادة ولا تفارق الابتسامة شفتيه

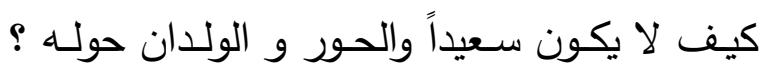
فالحور شكلهن شديدات بياض الأعين ، شديدات سواد سوادها ، مع بياض البشرة وصفائها ونقائها وقد تعدقوا في وصفهم واستقوا مـادة تشبيههم من أسلوب القرآن الكريم تميز به من دقة في الوصف

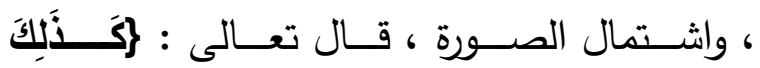

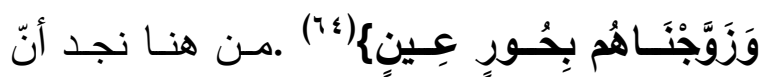
الثـعراء الأندلسيين قـد ذكروا حـور العسين في نصوصهم الشعرية متأثرين بالأوصاف الواردة في القرآن الكريم ، وقد استمدوا هذه الصفات في رسم

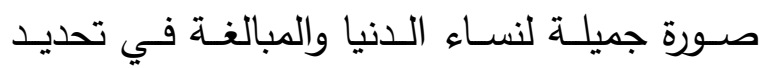
( (؟) سورة الدخان : آية :؟ه . 
مهمـا حساول الإنسـان أن يعهر في دنيـاه

فيبني ويشيد القصور و يزرع الأراضي و الحدائق و البســاتين ، حيــث أنّ الحيــاة العصــرية فــي ولري

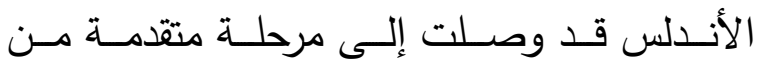
التحضر و الازدهار و الرقي ، فإن هذا سيبلى و يـزول وينتهي و كل مـا بـذل الإنسـان فيـه جهداً سـوف يعـود إلى الأرض ترابـاً ، فالإنسـان الــي يتخيل أنـه بعمله و تشييده لهذه القصور و المدن و الحواضر قد وصل إلى مبتغاه و نجاحه و توقع أنـه معمر في هذه الدنيا فإنـه يعد نفسـه قد أخلد الخلود الأبدي لكن الحقيقة على عكس ذلك لأن العـيش الأبـدي هـو فـي الأخـرة فيصـبح سـكن الإنسـان أمـا في الجنـة التي يكـون الدخول إليها بواسـة أعمالـه و كأنـه يعد مفتـاح الـدخول ، أو لو يكون إلى النار التي يدخلها أيضـاً بأعماله ، لكن

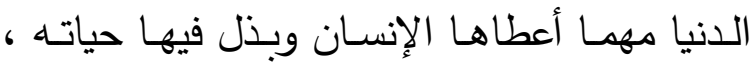
وأخلص لها ، فأنها لا تجازيـه بخير و إنما تقف هـ ضده و تملأ حياته شقاء و لا تسعده و كل همها أن تأخذ من الإنسان أكثر و أكثر حتى تخور قواه ، فأهم فـوز هو الفوز بـالأخرة ذلك الذي يتمنـاه الجميـع و يحظى بـه كـل مـن عمـل مـا أمـر الله سبحانها و تعالى ، و يقول ابن أبي الزمنين (^^):

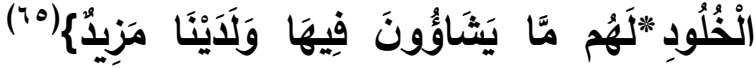
ومن بين هذه الصفات : أ. شعور أهل الجنة بالرضا والسرور والفرح : لقد استلهم شـعراء العصـر الأندلسي مـن الصـور القرآنية و مفاهيمها التي وردت لوصف النعيم اللا محسوس في الجنة ، ومن هنا نجد وصفهم للحالة النفسـية لعبـاد الله الصـالحين ، حـين يقضــي الله سـبحانه وتعـالى بيـنهم ، و يحكم لهـم سـبحانه بدخول الجنة و النجاة من النار ، و إن مجرد أن يبتعـد المـؤمن عـن النـار ، فهـي نعمــة روحيـة عظيمة و يشعر بحالة نفسية مرتاحة إلى أبعد حد و يأمن من غضب الله سبحانه وتعالى والنجاة من النـار و مـا ينتظر الفاسـقين مـن عذاب شـيد لا يهدأ ولا ينقطع ، حيث يقول مروان الطليق (ب7):

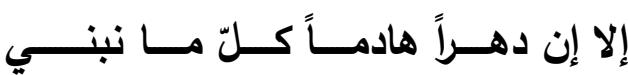

سيبلى كما يبلى و يفنى كما يفنــى

ومــا الفــوز فــي الـــنيا هوالفــوز إنمـــا

يفوز الفتى بالربـــــــ فيها من الغبنِ يجــازي ببــؤس عــن لذيــــن نعيمــــها

ويجني الردى مما غــــــت كنهُ تجني (TV) (10) سورة ق : آية : ؟r-0 . هو مـروان بـن عبد الـرحمن بـن مـروان بـن عبد

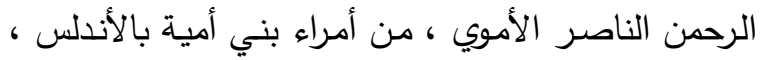

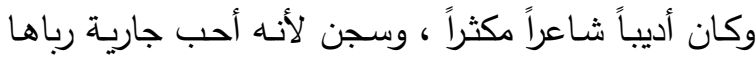

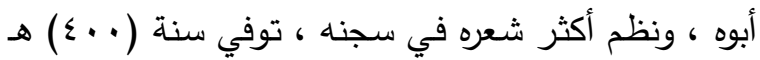

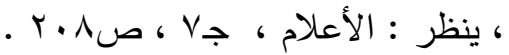

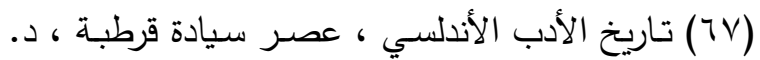

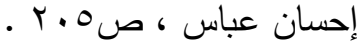


فالرحيـل عـن الــنيا هـو سـفر فيحـزم

الإنسان أعماله في حقيبة الرجاء تلك هي الأعمال

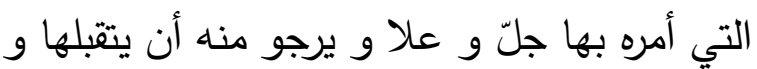

يرضى عنه ، فالذي يعلم أن قد أخلص في إنجازه و مشى على الطريق القويم فأنه لا يخاف أبداً و ألها

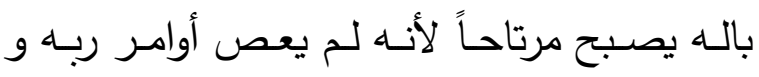
ينتظر فقط دخولهـ إلى المكـان الذي يسعد فيـه

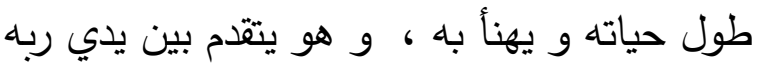

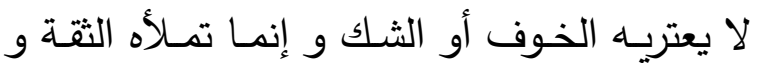
السعادة الغامرة لالتقائه بحبيبه خير لقاء و معسه أعمالـه ليسلمها إلىى ربـهـ كمـا أمـره بـه وبالمقابـل يعطيه الله مكاناً قد حجزه لـه في الفردوس ذلك لك المكان الذي يخلد فيه و لا يخرج منه أبداً . و قول لسان الدين : و أحط رحلي في كريم جوارٍ الاين أرجو نعيماً في الجنان مقيماً (v)

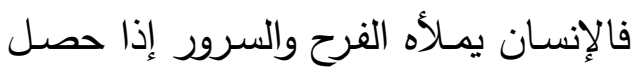
على مبتغاه فهو في فرح دائم و طمأنينة لا تتنهي

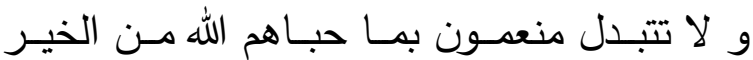

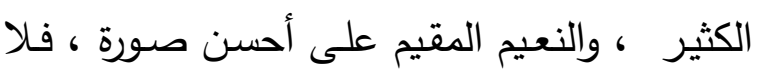
يصـل إليهم الهـم ، و لا يمـر عليهم الغـم و لا لا تضيق صدورهم ، و لا تستوحش نفوسهم ، و لا لا

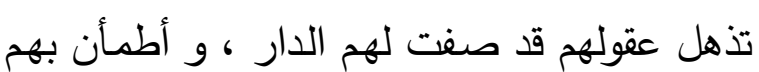
القرار (Vr) ، فهم يشكرون الله على فضـله و منــه

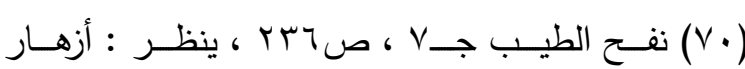

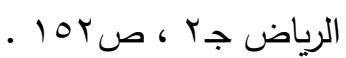

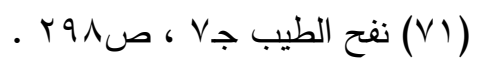
ينظر نعيم الجنة في القرآن الكريم والسنة ، د. عبد (VY)

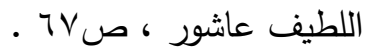

أيـــــها المرؤُ إن دُنياك بحرُ

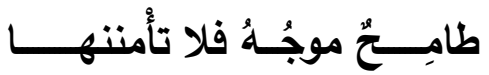

و سبيـل النجـــاة فيها مبين فلين

وهو أخذ الكفاف و القوت منهـان(79)

فالذي يركب قارب النجاة ليترك ما حوله

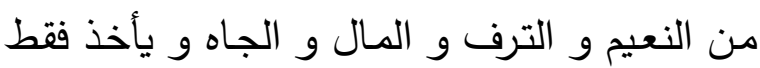
الذي يعينه على العبادة والصلاة ، فقد كان الزهاد ييتعـدون عـن المــن ويـذهبون إلـى الجبـال و الكهوف ليعبدوا الله في الخلوة و لا يلهيهم عن لئن ذلك شيء و طعامهم في ذلك شيء قليل ليعطيهم

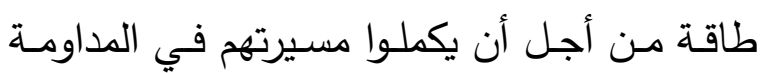

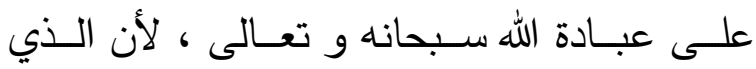
يعطي الأمان إلى الدنيا تصبح مثل أمواج البحر

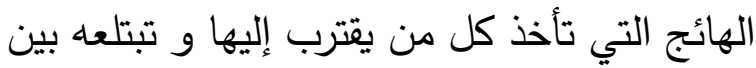

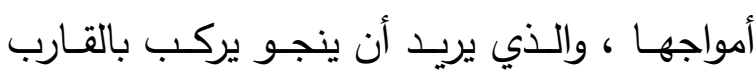
ليصل إلى بر الأمان و يفوز بالذي أعده الله له ، و أنثد ابن زمرك :

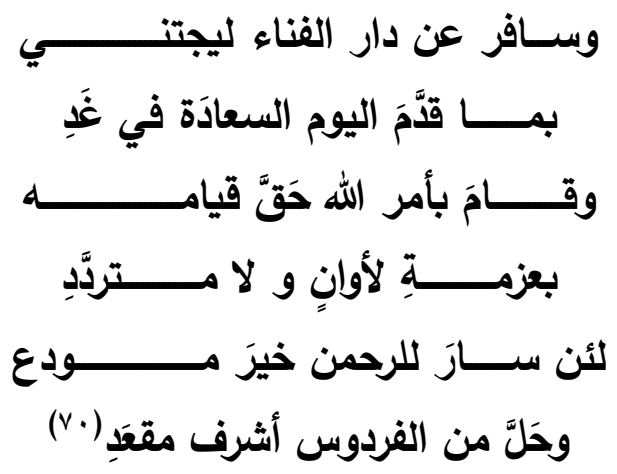

تاريخ الفكر الأندلسيس ، تـأليف انخل جنثالث بالنثيا ،

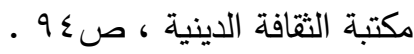
(79) يتيمة الدهر في محاسن أهل العصر ،لأبي منصور

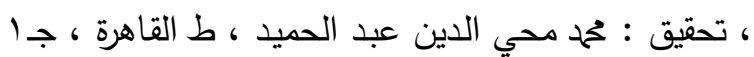
• 
ب. صحبة الأنبياء والصالحين في الجنة :

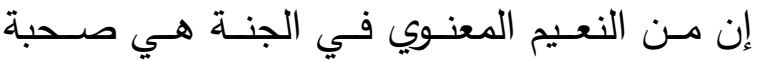

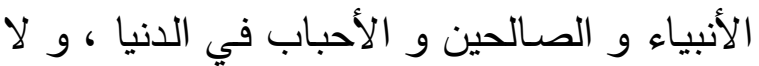

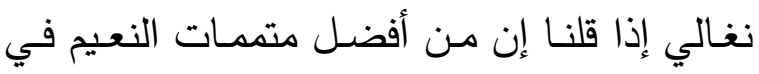
الجنـة هي الصحبة للصفوة المختارة من الأنبياء والمرسـلين و الثــهـاء والصــالحين ، و الآيــات القرآنية قد ذكرت أن بعضاً من أهل الجنة ستكون

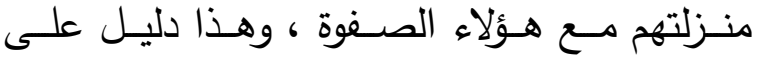
تشريفهم ، وطيب مآلهم ، و حسن منزلتهم عند الله سبحانه وتعالى ، و لاثك في هذا الموقف للمؤمن

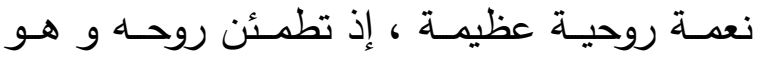
مستقر النفس هادئ الروح لعلمه أنه سيحظى بهذه الصحبة الطيبة من الصفوة المختارة ، فهذا دليل على تشريفهم و طيب مآلهم و حسن منزلتهم عند

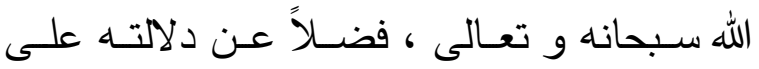
اطمئنانهم على حالهم لإزالة ما في نفوسهم من خوف(Vo) ، فمن ذلك قول سعدونة(vi) : لعلَّني أحظى بتقبيلهِ في في في

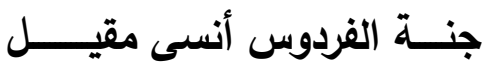

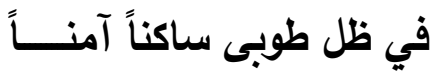
أُسقي بأكواسٍ من السلسبيل (vv)

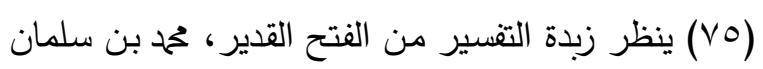

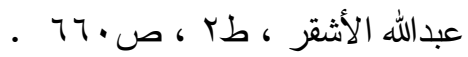
(VT) و تعرف سعدونة من النساء المشهورات بالأندلس و لها لها رواية عن أبيها و جدها و غيرها ، ينظر : نفح الطيب

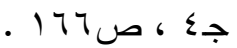
(VV)
بأن جعل إقامته دائمة في مكان العز و الهناء و

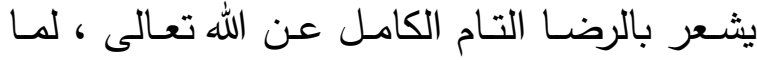
يجد من أنواع النعيم التي أعدات لهم في الجنـة

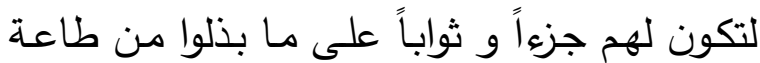

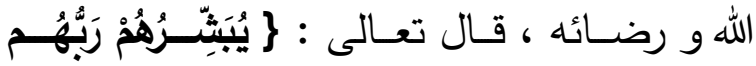

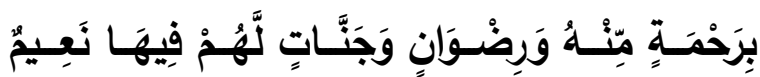

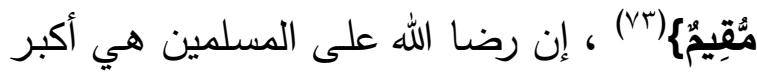
بشـرى و يغهـرهم الفـرح والسـرور بهــه النتيجــة السعيدة التي لا يحصل عليها إلا من رضي الله عنه ، و يقول ابن دراج :

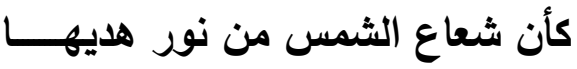

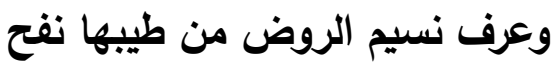

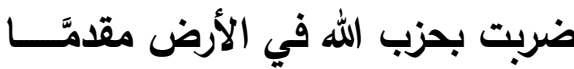

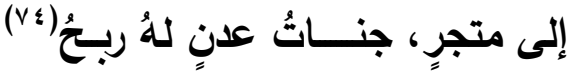

فالذي يضع هدفاً في حياته و يسير على ضوء ما

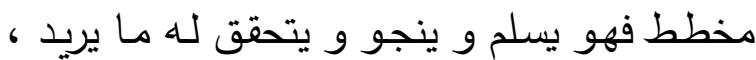
فالناس ينقسمون إلى فئتين ، فئة تدخل إلى النار و فئـة تدخل إلى الجنـة ، فكل إنسان بما عملته

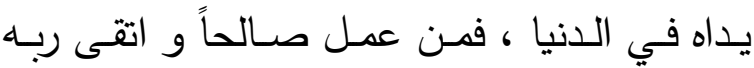
سيكون مع الرابحين أصحاب الجنة ، و من اجترح

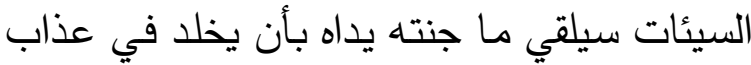
شديد خسر الدنيا والأخرة ، ومن هنا أشار الثاعر لإن إلى إن ذكر الفوز بالجنة ، والدخول لها هو الربح

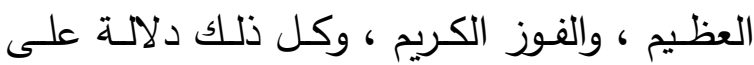
المبالغة في وصف النعيم الروحي للجنة ـ الن

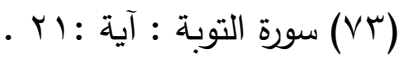

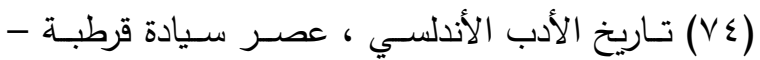

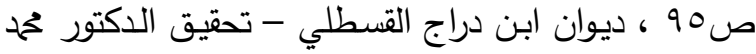

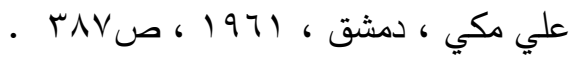


والثفاعة ، فيشـر المسلم براحسة جميلة لا مثيل لها ، فكل إنسان يتمنى القرب و التوسل بالنبي

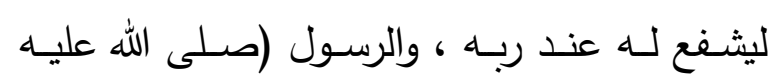
وسلم) لا يبخل على أي إنسان فهو كالأب الحنون

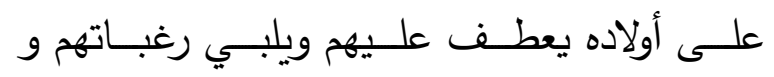

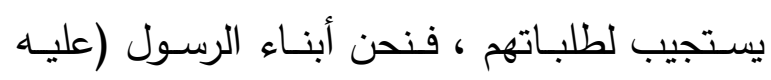

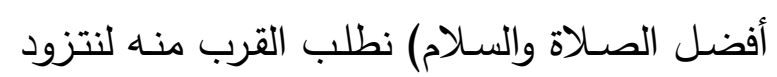

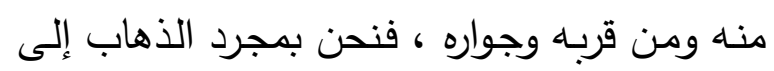

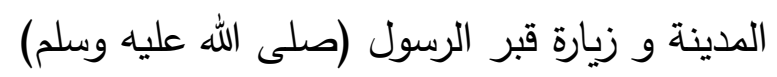
نشـعر براحـة لا مثيـل لهـا فكيـف فـي الأخــرة

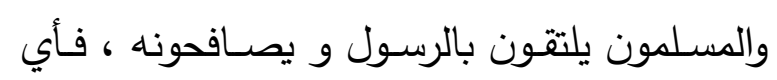

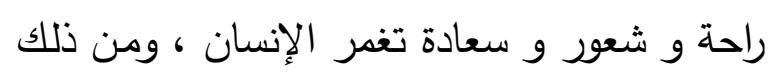

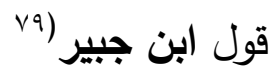

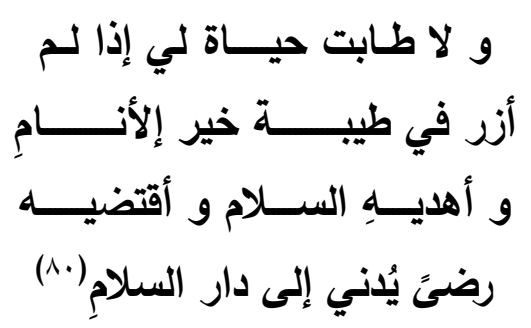

فلا ترتاح نفس المسلم إذا لم يذهب إلى طيبة ذلك دلك الكي الدكـان الذي يوجد فيسه قبر الرسـول (صلـى الله

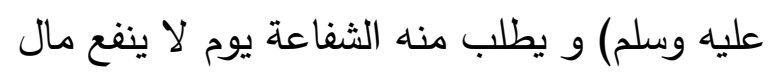

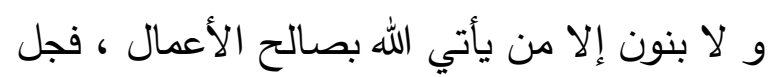

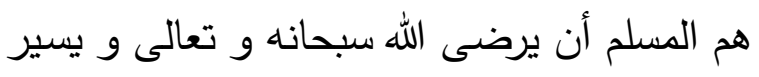
على ضوء ما أمره بـه ليرضى عنه الله ، و بهذا

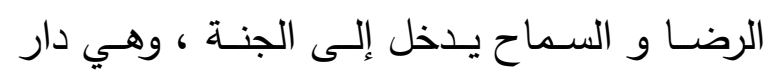

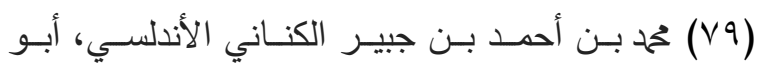

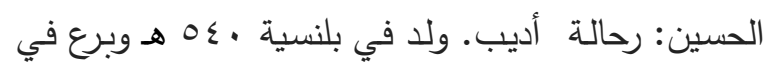

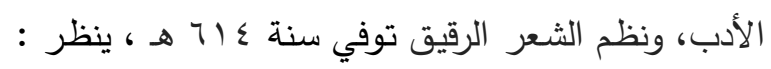

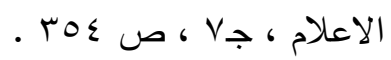

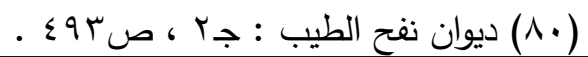

تتمنى الثاعرة إحدى الأمنيات وهي الوصول إلى لئى الجنة و تقبيل المصطفى (صلى الله عليه وسلم) لأن المسلم بمجرد دخوله الجنة التي يكون الدخول

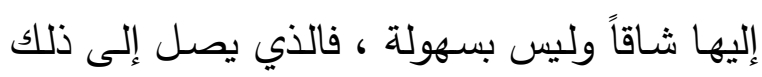

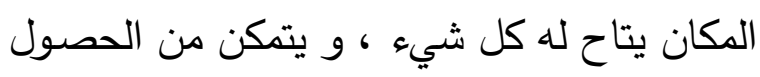
عليه بثتى الطرق حتى و إن كان صعباً عليه في الدنيا ، من ذلك جوار الحبيب الدصطفى (عليه أفضل الصلاة والتسليم) فهناك العيش الرغيد تحت ظلال الأشجار الوراقة والأغصـان المتدلية بالثمار

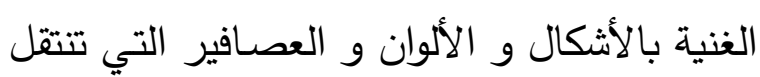
من غصن إلى غصن ، كل هذا يدل على الأمان

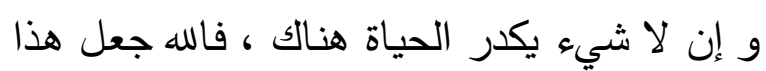

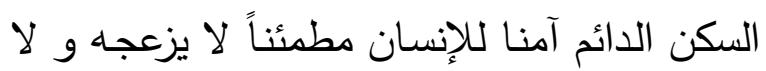
يضايقه هم ولا غم لأن هذه تزول بانتهاء الحياة

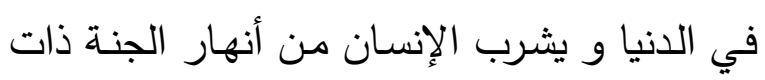

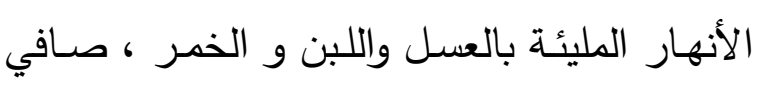

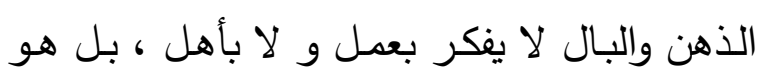

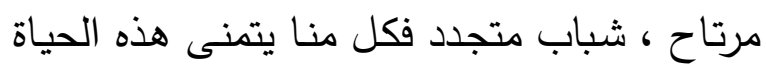

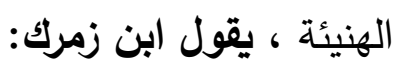
يؤمون من قبر الثفيع مَثابـةً

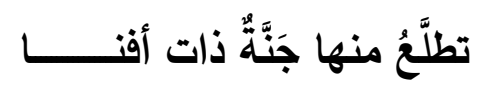
إذا نـزلبوا من طـيبةٍ بجـــــــــاره

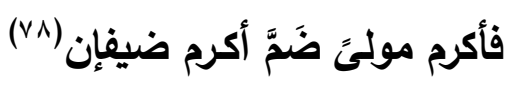

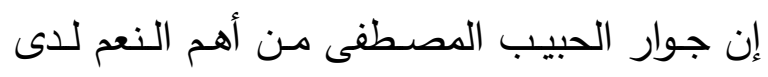

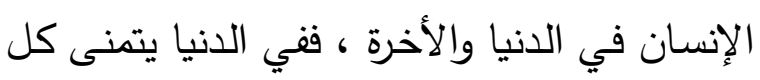
مسلم زيـارة قبر الحبيب (صلى الله عليهه وسـلم) وتقبيل ذلك المكان المبارك ، وطلب الرحمة منهـ نفح الطيب : جـ (V^) 


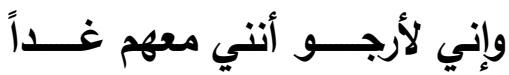

وأن لستُ عنهم في الجنـــانِ بمبعد إند

على المصطفى و الآل و الصحبٍ

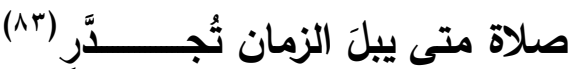

إن أصـاب الجنـة يثـعرون بالغبطـة و الارتيـاح في صـــبة النبـي (صـلى الله عليـهـ وسـلم) و أصــحابه إذ يقيمـون فـي دار لا نقلـهـ عنهــــا ولا تحول فضـلاً عن مصـاحبة الأنبياء و الصـالحين فيها ، فكل مسلم يتمنى أن يلتقي بكل نبي و بكل

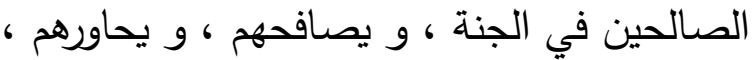
و يتلهـف لـرؤيتهم مثل تلهـف الأم إلىى ولـدها الصـير عند رؤيته ، و في الوصسول إلى ذلك لكالك

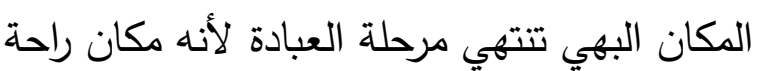
، فالراحـة هنـاك تكون في جمـال المكان وطيب الكيب

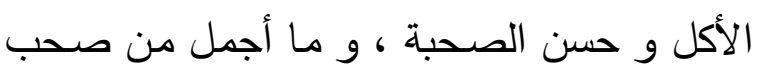
الأنبياء و الصـالحين و جوارهم الجنة و التحدث التهن إليهم ، وقول ابن جابر : لقد أســـــَ الرحمنُ جارَ محمدٍ

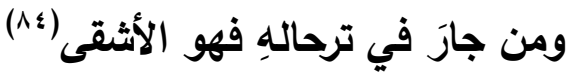

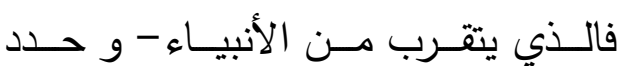

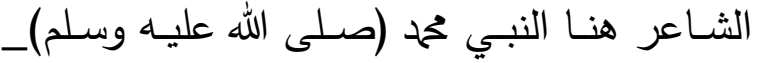
تملأه السعادة والغبطة و حسن حديثه و مزاجه ، و لا يتكدر أو يتضـايق في حياته ، والذي يظلم

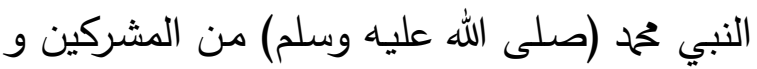
الكفار فهم الأشقى في الدنيا و الأخرة لأن الإنسان الهن

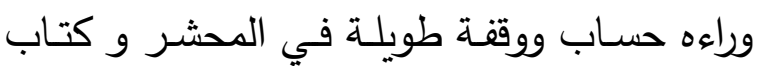

(^r) شعر ابن جابر الأندلسي ، منحسه الدكتور أحمد

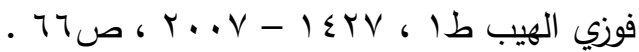

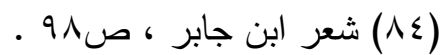

السـلام مـن غير شكك و لا حـاجز ، دار السـلام

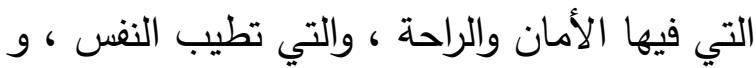

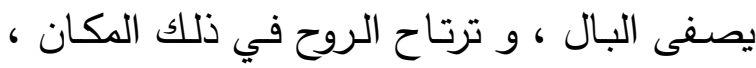

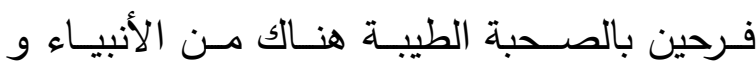
الأولياء و الصالحين ، حين يقول ابن عبد ربه :

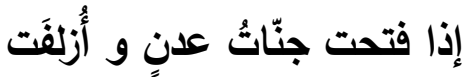

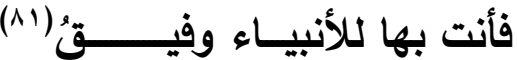

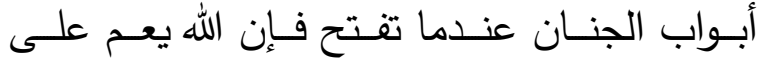

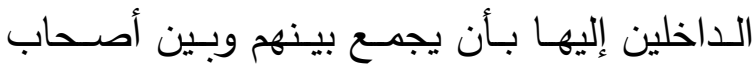
المقامات العليا ، ومـن يحبون من ذويهم ، و لا لا

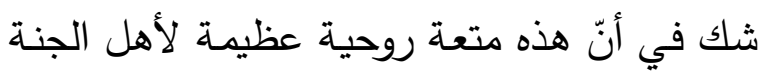

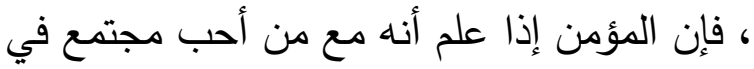
الجنة ، شعر بأنه قد اكتملت متعته ، وإن مرافقة الدان الأنبياء و الصـالحين و الثهداء في الجنة تعطي

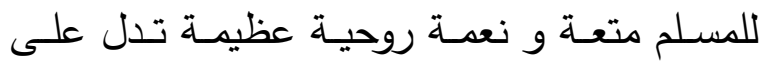
عظم شأن المرافق و إكرامه و تشريفه . وقد تأثر الشعراء بأسلوب القرآن الكريم في كلامهم على الرفقة في الجنة ، إذ قال تعالى : طوَمَن يُطِعِع

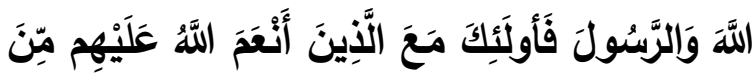

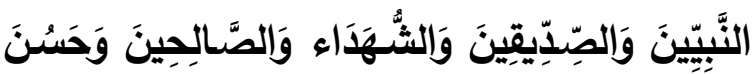

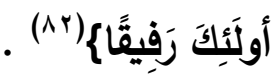
و يقول ابن جابر الأندلسي :

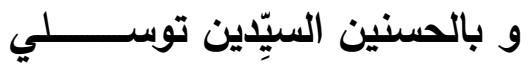

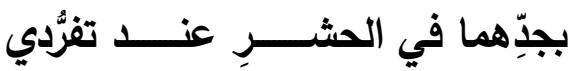

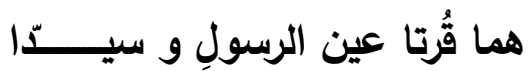

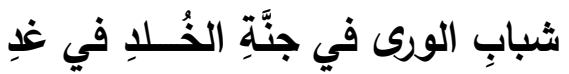




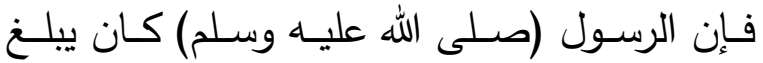
السسلمين على لسـان الله سبحانه و تعالى بأنهم

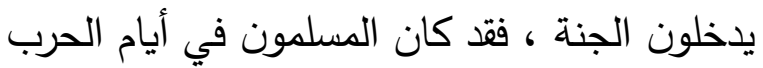

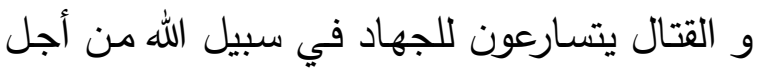
نصـرة الإسـلام و جعل رايتها عاليـة ، والرسـول (صلى الله عليه وسلم) كان يخبرهم بأنهم يتبوؤون

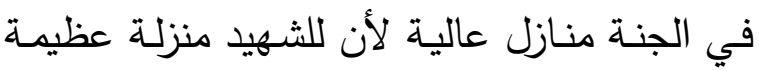

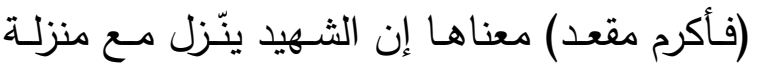
الأنبيـاء و الصـديقين ، و هـي منزلــة يستحقونها لأنهج لم يترددوا في استجابة لطلب الرسول (صلى لانى

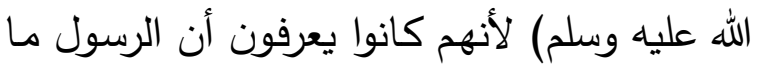
ينطق عن الهوى و إنمـا كانت تعليماتـه من الله سبحانه و تعالى عن طريق الوحي جبريل (عليه السـلام) ، و إن هذه البشـرى هي رفع معنويـات المسلمين و مكافأتهر على أعمالهم بأن لهم مكاناً

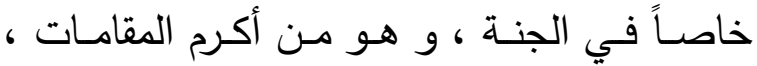
وعلى هذا النحو قول ابن جابر : وقال رسول اللهِ أوجبَ طلحةٌ هابِ و أبدي جهادَ الناصح المتجلّدِ

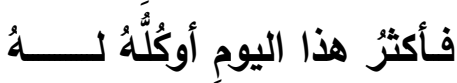

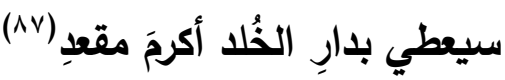

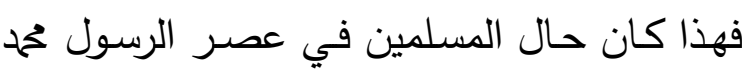

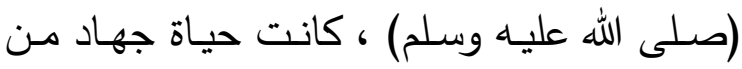
أجل إعـلاء رايـة الإسـلام ، و كـان المسلمون لا لا يتوانون عن تلبية نداء الرسول (صلى الله عليه وسلم) الذي كان يشجعهم و يحثهم على الجهاد و يرفع من معنوياتهم النفسية بتذكيرهم بما ينتظرهم
مفتوح تبين كل ما عمله في حياته الدنيا ، و يزاح عن الجنة أهل النار ، و يعلم الكفار عقبى الدار ، فالمؤمن من النعمة التي أنعمها الله عليه يجاور من أحبهم و يبقى معهم في الخلد ، لا يفرقهم أي من التعانه

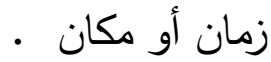
ج. الحفاوة و التكريم لأهل الجنة :

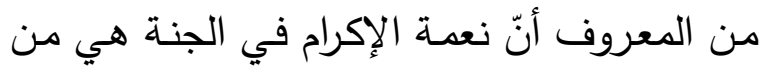

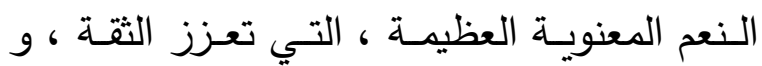

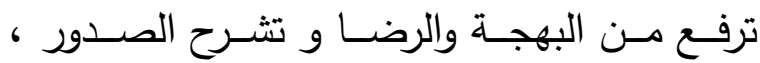
فالضيف في الدنيا إذا لقي في دار مضيفه مزيداً من الحفاوة والتكريم و البشاشة استقرت به نفسه و زادت راحته ، عكس ما لو لم يجد هذا التكريم فأنه سيحس في نفسه غصة و ألماً تعكر عليه صفوة ولذتـه ـ وإن الله جل وعلا في دار الأخرة سينعم

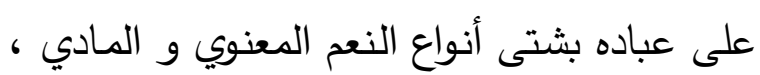

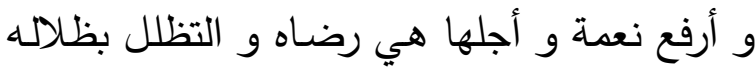
، فلا يخافون وهم في ظل الجبار القوي شيئًاً ،

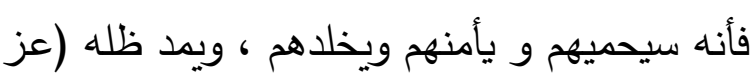
وجل) على عباده في جنته ، وقد ذكر الله في

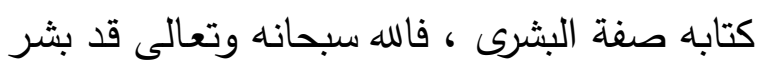

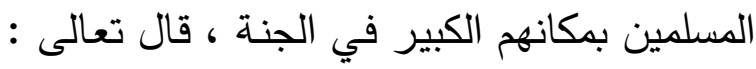

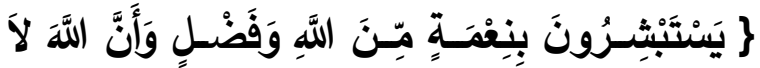

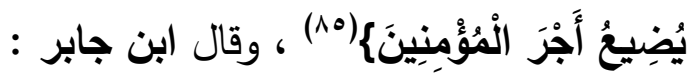

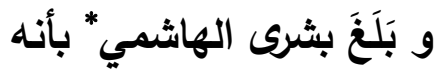

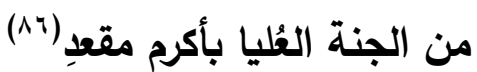

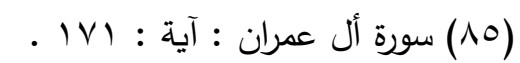

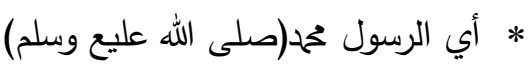


وقد قيل للفاروق : هذا ، ومن بـه

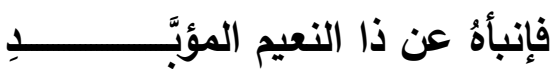

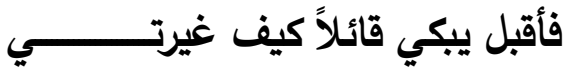

عليك ،و لولا أنت ما كنت أهتدي)(9)

و نلاحظ من قول الشاعر أن الرسول (صلى الله عليه وسلم) كان يبشر الصحابة بما ينتظرهم من تكريم مـن الله عز و جل لهـم ، و هذه المكانـة محفوظة لهم مهما طال الزمن إذا سـار الإنسـان على نفس منهجه و تقواه و عمله في الحياة الدنيا ، و فـي البيــت الأول إشــارة صــريحة إلـى أن

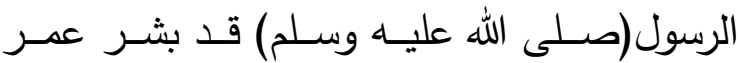

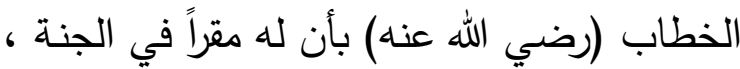
وهـل أجمـل مـن هـذا التكريم و العطـاء مسن الله سبحانه و تعالى ؟ فالهه يعطي بغير حدود لكل

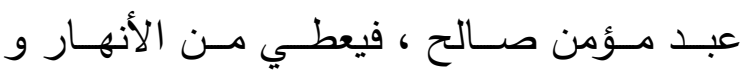
القصور و البساتين ، فالعبد المؤهن عندما يدخل إلى الجنـة يجد أن كل شـيء متوافر و يعود لـه فيتعجب فيسأل الله سبحانه و تعالى ، فيجيبه عز وجل إن هذه ثمرة عملك في الدنيا و جدته هنا ، فكل واحد يلاقي ما كان يفعل على الأرض فإذا

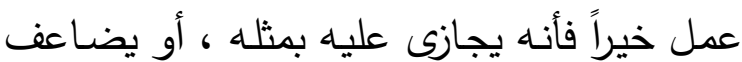
له مرتين فمن نجد مثل الله عز وجل و مثل هذا الكـرم الـوارف ؟! ، ومـن ذلـك قـول ابـن زمـرك

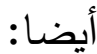

(91) يشير إلى الحديث :"دخلت الجنة فوجدت فيها دارا

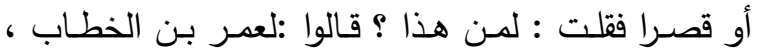
فأرت أن أدخل فذكرتك غيرتك ، فبكى عمر وقال : أي هد

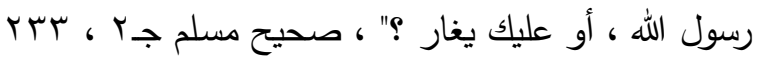

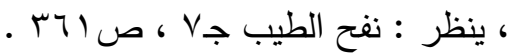

مسن عـز و جـاه و مكانـة عاليـة في الجنـة ، و عنـدما نعـود إلـى الثـعراء نجـد أن الثـعراء قـــ اسـتقوا أبياتهم الثـعرية مـن القرآن الكريم فكلمـة (مقعد) هي ورادة في القرآن الكريم و (هي مجلس حق لا لغو فيها و لا تأثيم)(^) ، فمجالس الدنيا تختلف عـن مجـالس أهـل الجنـة ، قـال تعـالى :

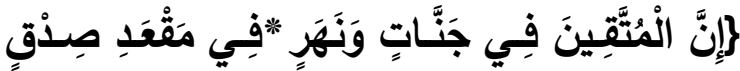

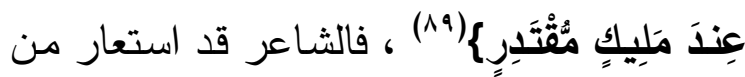
القرآن كلمـة مقعـد و هي أقرب كلمـة تدل على ملى تكريم أهل الجنة و أن لهم مجالس خاصة لهم في الجنة يستطيعون أن يلهوا و يمرحوا فيها من غير أن يحسبوا حساباً لوقت أو أي عمل من أعمال الدنيا ، فهل يوجد شيء أحلى و أجمل من هذا التكريم الذي أعطاه الله للمسلمين على كل شيء عملوه في سبيل الله وتحت لـواء الرسول (صلى الله عليه وسلم) فكل من يتبع أوامر الرسول فأنـه يهنأ بتبوء مقعده في الجنة ، قال ابن جابر : لهُ الجنة العليا بذلك فاشترى

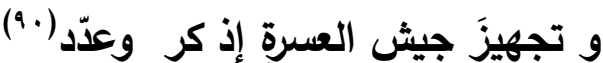

فالرسـول (صــلى الله عليـه وسـلم) كـان يبثـر المسـمين في وقت الحرب بأن لهم مكافأة في الجنــة ، و هـي مكانـة في الجنـان العليـا التي يسكنها الأنبيـاء و الأوليـاء و الصـالحين و هـذا تكريم لهم من الله سبحانه و تعالى و حفاوة لهم منـه سبحانه و تعالى على صنيعهم ، ومن ذلك قول الشاعر ابن زمرك:

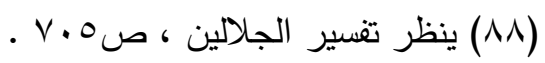

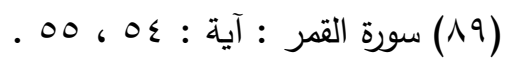

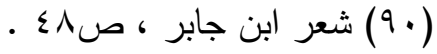


د. الخلود لأهل الجنة :

مهما طال وكثر نعيم الدنيا فهو زائل لا محالة ، أما بالموت أو بغيره ، لذا كان نعيم الدنيا ناقصـاً لاحتمال زواله ، والمعروف أن النعيم في الأخرة هو دائم ، لا يصيب صساحبه الملل و لا السقم و

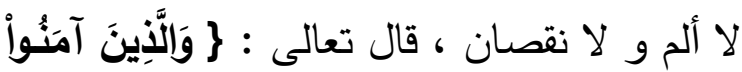

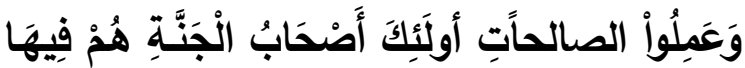

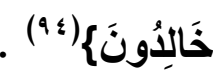
وإن البشارة بالخلود لأهل الجنة إيحاء إلى علو هذه الدرجة ، من ذلك قول لسان الدين : و أحط رحلي في كريم جوارِ

أرجو نعيماً في الجنان مقيماً (90)

يثير الثاعر في بيته إلى معنى السفر فهو يحمل أعمالله معسه و يغـادر الحياة الدنيا إلى مقر ودار

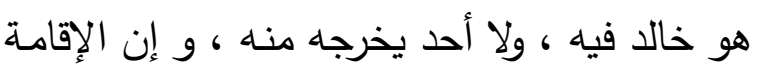
في هذا المحل إلى أبـد الآبدين ، قـال تعـالى :

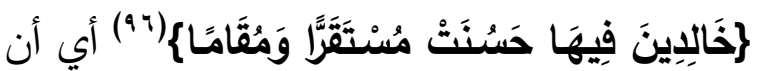
في الجنـة خير إقامسة لخير مقيم فيها ، لكن أن يقيم الإنسان وحده في هذا المكان الجميل يشعر بالوحـدة فجـوار الأنبيـاء و الصـالحين و الثــهداء هي من أجمل الصحبة هناك ، و كيف لا يطيب للإنسان العيش في هذا المكان الجميل الذي من

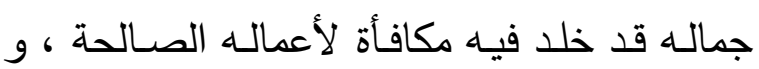
يقول ابن زمرك : - مئ

فلا زلتَّ في ظلِّ النعيمُ مُخلـــــــــاً

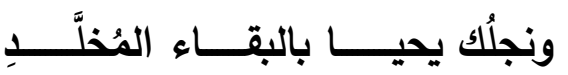

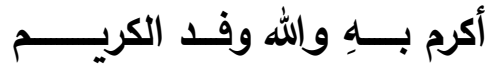

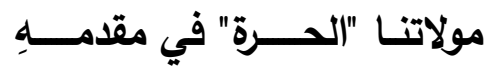

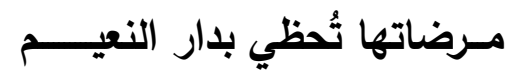

وتـوجب التوفيق من منعمــــهِ

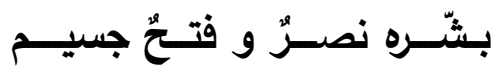

$(a r) d$ وخيرةُ أجمــع في مَقِدِمـ لقـد ذكـر ابـن زمـرك في موشـحته و هـو يهنئ السلطان موسىى ابن السلطان أبي عنان وقد وجه إليه الغني بالله أمه و عياله عند تملكه المغرب ، فنـلاحظ أن الإنسـان مهمـا عمل خيـراً فإنه يتوقع أن يكون له مكان مميز في الجنة ، و الإنسان لا يلمس حلاوة صنعه في اللحظة نفسها ، و إنما تتجمع لله في الجنة ، فكل عمل صـالح نقوم بـه من طاعـة الله و رسوله و تلبيـة طلباتهم من غير تردد ، فإننـا نحصـل على كرم من الله هو مكاننا الخاص في الجنة من غير أن يزاحمنا

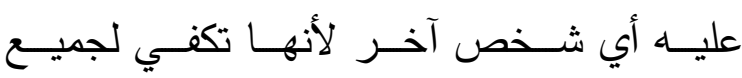
المسلمين و أكثر ، ويقول ابن زبدون :

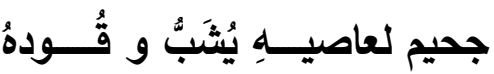

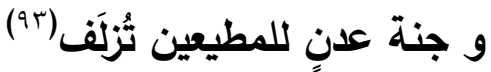

نلاحظ من هذا البيت أن الله سبحانه و تعالى قد أعد للمسلمين جنات عدن و في الوقت نفسه فأنها قد أعد للكافرين نـار جهنم فكل حسب تقواه ، وحسب عمله ، و ليس بحسب جاهه أو ماله. .

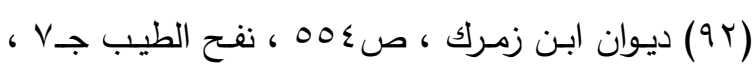
ص ص

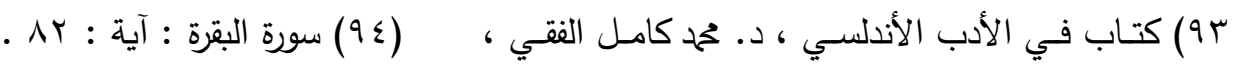

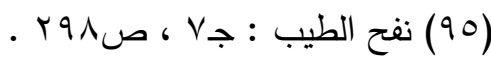

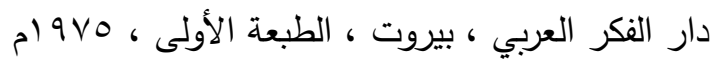

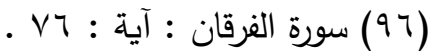


هذا فإن الله سبحانه و تعالى قد أكرمـه ووضـعه في أحسن منزلة فهو لـه مكانـا العالي في الجنان العليا مقيم فيها ، و كل من أراد الإقامة في منزلة

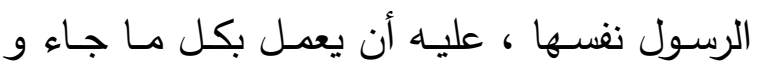
يلبي كل ما أمر بـه حتى يلتقي بـه في جنـة الخلد و يقيم مسع أولياء الله ، وقول أبي الحجاج يوسف بن موسى المنتشاقري الأندلسي(.') :

قد سمــــا قدرهُ بغيرتنــــــا هي

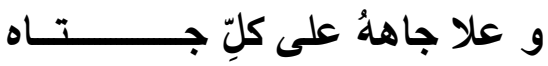

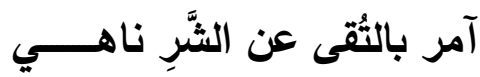

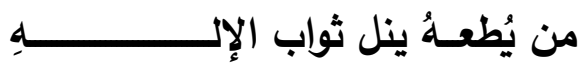

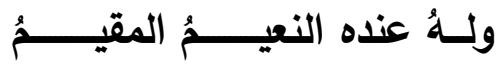

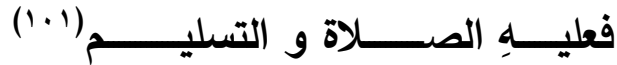

فكل من يطع الرسول ويسير على ضوء ما كان يأمر به ، و يعرف طريق الحق من طريق الظلال

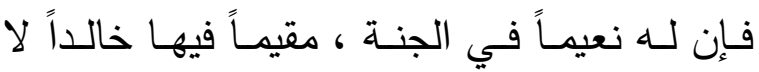
يموت فيها ، فهي تكون بعكس الحياة الدنيا التي يعيشها فما فائدة المتع المادية للإنسان من مأكل ومشـرب و منـزل و يـوقن بعـدها بنهايتهـه و أكيــ فنائهـه ، و لكن أهل الجنـة لا يموتون و لا ينقطع نعيمهم و تكتمل سعادتهح و هناؤهم ، بتوافر جميع المتع و الملذات و ما تشتهيه أنفسهم ، فمن يطع الله ورسـوله ينـال مـا يريـد فـالله سبحانه و تعـالى لـ يعطي عبده الذي يتمناه إذا أطاع الرسول (صلى

(ع) ابي الحجاج يوسف بن موسى المنتشاقري الأندلسي

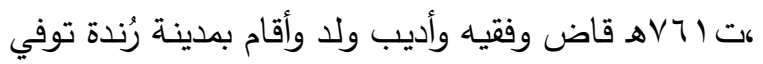

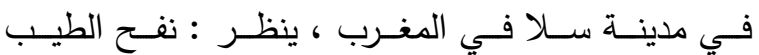

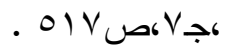

و أوردَكَك الـــــرحمنُ حوض نبيــــهِ

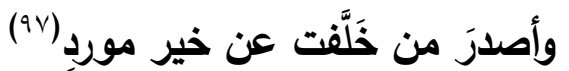
يبين الشاعر أن اللذة في الجنـة دائمسة ومستمرة ما

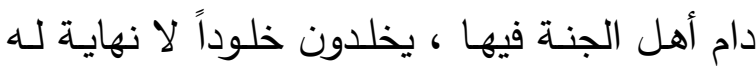
في الجنة في أفضل حال ، ومن عطاء الله على المسلمين و فضله عليهم هو ورودهم حوض النبي

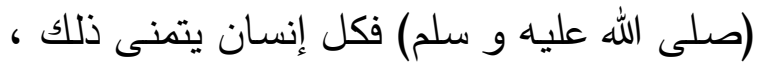
ومن ذلك قول ابن الجنان(9^) : جلَّتُ مَناقبُ خــاتم الرُّرسل الأي بالنـور خَتم و الههى تختيـــماً

وسمت بـه فوق السمـــــاء مراتبُ

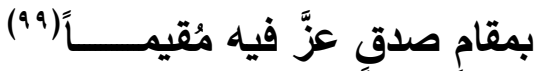

نـرى في هـذه القصـيدة أن ابـن الجنـان قد مـدح الرسول (صلى الله عليه وسلم) فهو خاتم الأنبياء و كانـت رسـالته هـي هـدي النـاس بمـا أمـر الله سبحانه و تعـالى و مشىى على هذا النهج الذي لذي وضحه له الله فكان الرسول هداية للأكمة جمعاء ولى و بـه نقتدي ، و بـ نتمسك ، فالرسول (صلى الله

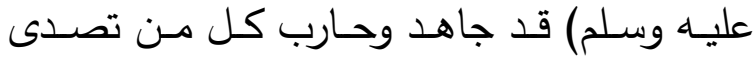
لللدعوة و تحمل الأذى في قلبه و كان يكتم غيظه ، فهو العليم الصبور ، الصـادق الأمين ، ومقابل

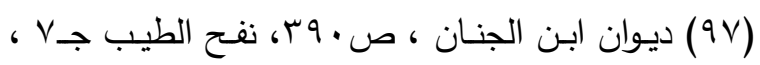

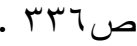
(Y) هـو أبـو عبــ الله محمد بـن محهد بـن أحمـــ الأنصـاري المعـروف بـابن الجنـان ، مـن علمـاء عصـره المشـهورين

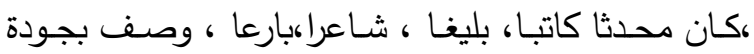

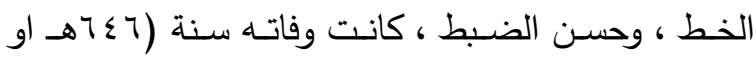
1 ז آهـ)، ينظـر :ديـوان ابـن جنـان ،ص 9-9 19 ، نفـح

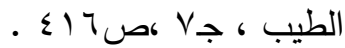
(1 (1) المصدر نفسه الجزء و الصفحة . 
ملائكته على عباده و رضاه عنهم و الفوز بالجنة و نعيمها ، و إنما ضمنوها في نصوصهم الثعرية السابقة تراثاً زاخراً بالمواعظ و الحكم التي تحدث على عمل الخير للظفر بما يتمنى هؤلاء الشعراء الفوز به إلا و هو الجنة و رضا الله (عز وجل). وخلاصة قولنا : لقد استطاع الثعراء الأندلسيون توظيف المعاني الإسلامية التي جاءت مخصصـة

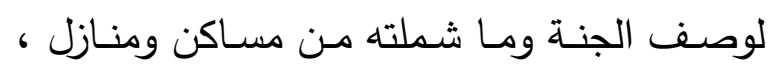
ومـا تضمنته من غرف ودرجات وعلو أو مقام ،

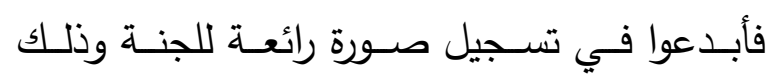
بإضـافتهم أوصـافاً من خيالهم الخصب مما ساعد

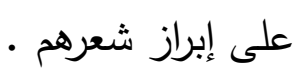

\section{الخاثمــة :}

أما في بحثنا للجنان في الثعر الأندلسي فقد اتضح لنا أن الأندلسيين قد تعاملوا مع دفردات

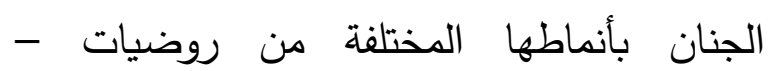
وزهريات - وثمريات - ومائيات على نحوِ خصب دون وواسع بما يتناسب والتعداد الوافر له ، إذ أفاد الثعراء كثيراً مما وفرته البيئة الأندلسية وجنانها الغنية ، لذلك تعاملوا مع كل مفردة من مفرداتها على النحو الذي يستغلون دلالاتها وصفاتها

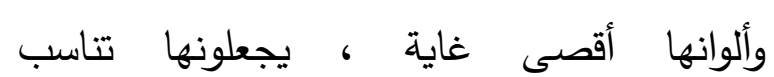
موضوعاتهم إن غـزارة مفـردات الجنـان فـي البيئـة الأندلسـية

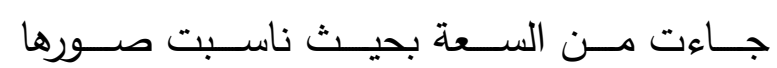
موضـوعاتهم الثعرية على مختلف أنواعها ، من غزل ورثاء وفخر ومدح وغير ذلك . وقد اعتمد الشعراء شتى فنون البيان والبديع في إظهار صـور الجنـة والجنـان مـن خـلال التعامـل
الله عليه وسلم) ، و قال تعالى : جوَمسن يُطِعِ اللَّة

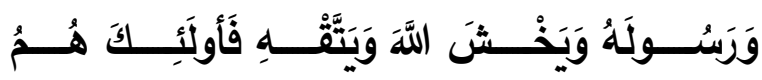

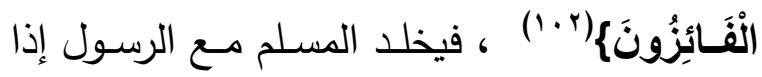
أطاعه و يربح الربح الكبير هناك في الأخرة ، و يقول ابن زيدون :

سيخلد في الانيا بهِ لك مفخَــرُ و يَحسُنُ في دار الخلود مآبُ (ז.)

فالثاعر هنا يوضح لنا نقطة مهمة و هي أن الإنسان لا يخلد في الدنيا و يبقى فيها العمر كله و إنما قصد أن الإنسان سيخلد بعمله ، فالأعمال الصالحة هي التي تبقي ذكر الإنسان إلى أبد الأبدين ، لأن سيرته بعمله الطيب و خيراته التي أعطاها إلى الآخرين تبقى على ألسنتهم ، فعمله يخلده و روحه تخلد في الأخرة في المكان التي تستحق أن تذهب إليه إلا و هي الجنة ، فإن الله يكرمه الجنة التي يخلد فيها ، و هذا أجمل عيش إل ففيه الراحة لا الثقاء ، و طيب المجلس و حسن الصحبة . و نلاحظ مما سبق اشتمال تصوير الشعراء الأندلسيين للصفات الواردة في القرآن الكريم للنعيم المعنوي لأهل الجنة و تأثرهم بها و ذكرها أكان ذلك نقلاً من القرآن الكريم أم ابتكاراً لصفات خيالية مستنبطة من مخيلة الثاعر الأندلسي تشكل من ذلك كله في نهاية المطاف صورة متكاملة و مبتكرة لنعيم الجنة المعنوي ، ولم يقتصروا على ذكر النعم التي أعدها الله لعباده في الجنة من الراحة و الأمان و سلام الله تعالى و

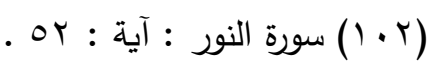

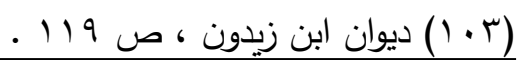


• جـامع البيـان عـن تأويـل آي القـرآن ، لأبـي جعفر محمد بن جرير الطبري ، تحقيق الدكتور

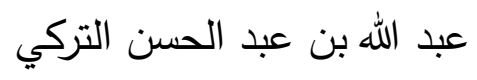

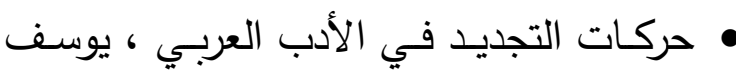
خليف، الطبعة الأولى ، دار الكتب العلمية .

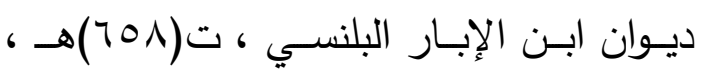
تحقيق: د. عبد السلام الهراس .

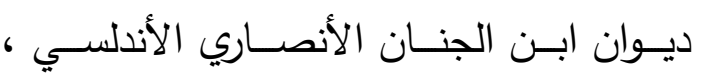

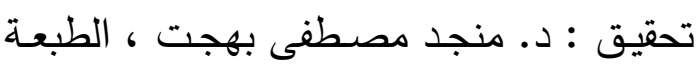

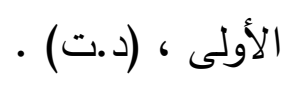

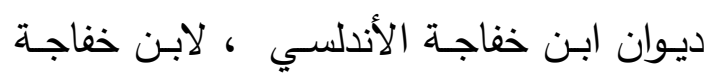

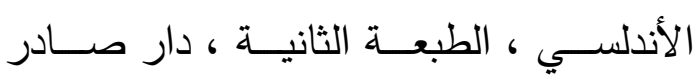

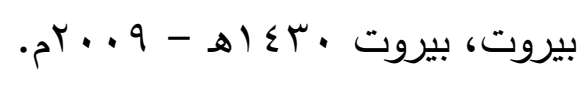

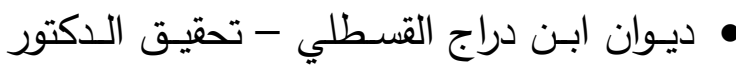

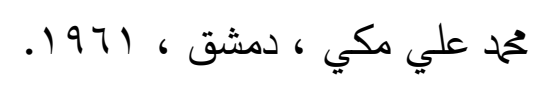

ديوان ابن زمرك ، تحقيق : محمد توفيق النيفر

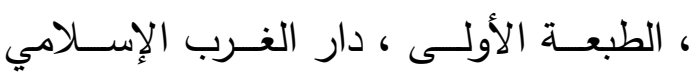

ديـوان ابـن زيــدون ، شـرح وتحقيـق: كـرم

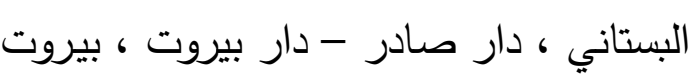

$$
\text { • }
$$

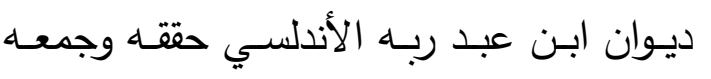

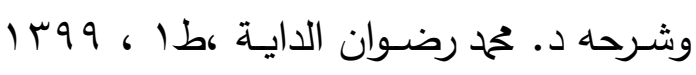

$$
19 \vee 9-
$$

ديــوان ابـن هـانئ الأندلسـي ، دار بيـروت

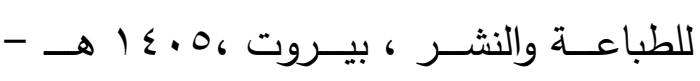

المناسب الذي خدم تثكيلهم التصويري في إطارها على نظم مخصوص بيد أنهم تأثروا بما تعامل به الهيه

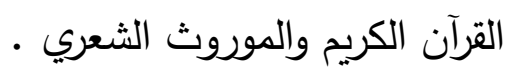

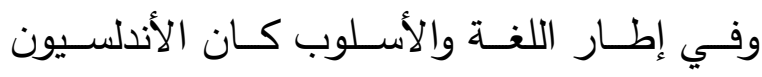

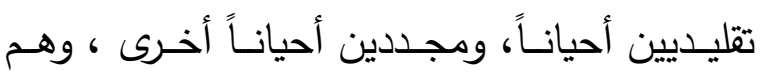

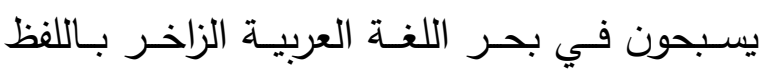

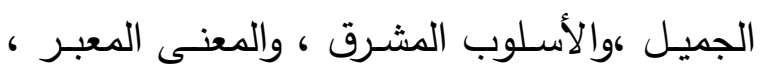

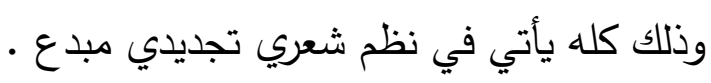

\section{المصادروالمراجع}

أولاً : المصادر - - القرآن الكريم - - الحديث الثريف الكرن -

ثانياً: المراجع

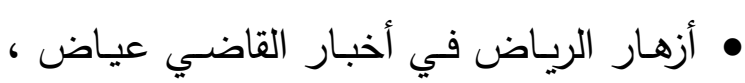

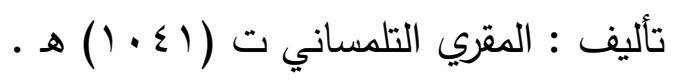
• الأعلام ، خير الدين الزركلي ، الطبعة الثالثة

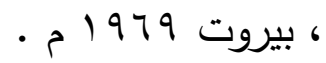
• تاريخ الأدب الأندلسي عصر سيادة قرطبة ،

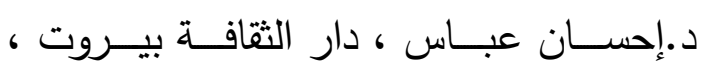

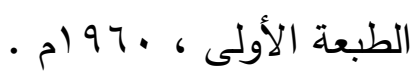

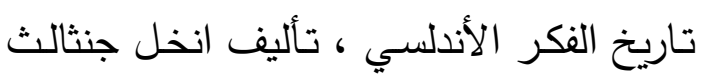

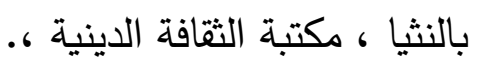

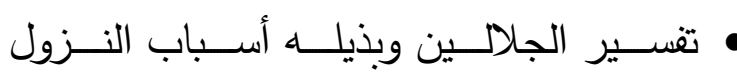

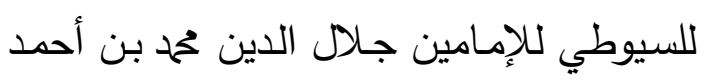

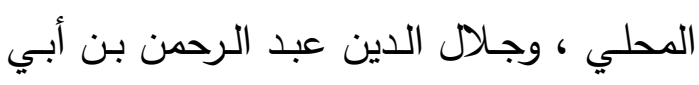

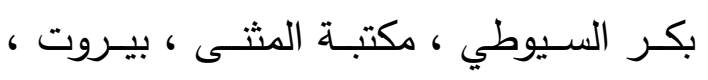

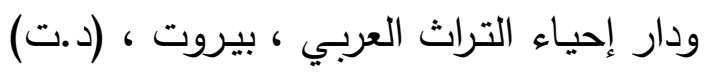


ه المجمم الـوجيز ، د. إبـراهيم مـدكور ، طبعـة

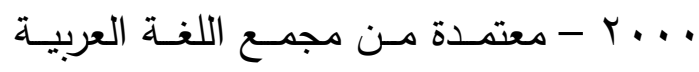

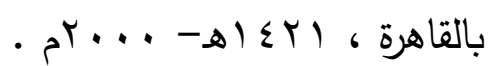

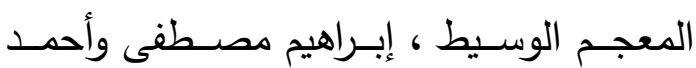
حسن الزيات ، وحامد عبد القادر ، وقحمد علي النجـار ، أشـرف على طبعـهـ : عبـد السـلام هارون ، دار إحياء التراث العربي ، (د.ت) • نعيم الجنة في القرآن والسنة ، د. عبد اللطيف عاشور ، مكتبة القرآن للطبع والنشر والتوزيع

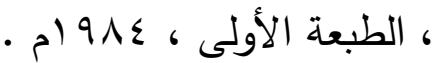

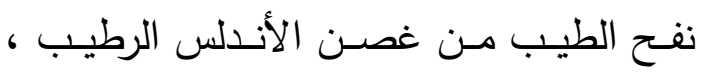
للشيخ أحمد بن المقري التلمساني ، تحقيق: د. احســان عبــاس ، دار صــادر - بيـروت ، - ) $971-81 T \Lambda \Lambda$ يتيمـة الدهر في محاسن أهل العصـر ،لأبي منصــور ، تحقيـق : عحمد محسي الـدين عبـد الحميد ، ط القاهرة
زبدة التفسير من الفتح القدير ، حمح بن سليمان

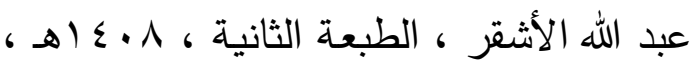
- ) 911 • شـعر ابـن جـابر الأندلسـي ، منحــه الـدكتور

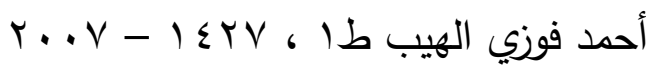

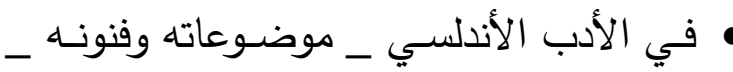

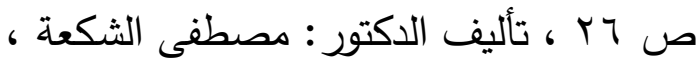

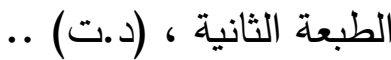
في الأدب الأندلسي ، د. كحمد كامل الفقي ، دار الفكر العربي ، بيروت ، الطبعة الأولى ، 5) $9 \times 0$ مجهـع البيان في تفسير القرآن ، للشيخ ابسي علي الفضل بن الحسن الطبرسي ، تصحيح وتعليق وتحقيق: السيد هثام رسولي المحلاتي ، والسـيد فضـل الله الزيـدي الطبطبـائي ،دار

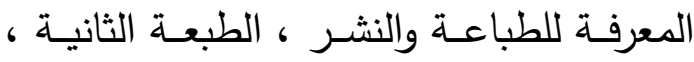
- م) $9 \wedge \Lambda-81 \varepsilon \cdot \Lambda$ 